\title{
Does the addition of labile substrate destabilise old soil organic matter?
}

\author{
Delphine Derrien $^{\mathrm{a}, *, 1}$, Caroline Plain ${ }^{\mathrm{b}, \mathrm{c}, 1}$, Pierre-Emmanuel Courty ${ }^{\mathrm{d}}$, Louisette Gelhaye ${ }^{\mathrm{a}}$, \\ Tanja C.W. Moerdijk-Poortvliet ${ }^{\mathrm{e}}$, Fabien Thomas ${ }^{\mathrm{a}}$, Antoine Versini ${ }^{\mathrm{a}}$, Bernhard Zeller ${ }^{\mathrm{a}}$, \\ Lydie-Stella Koutika ${ }^{\text {, }}$ Henricus T.S. Boschker ${ }^{\mathrm{e}}$, Daniel Epron ${ }^{\text {b,c,f,g }}$ \\ a INRA, Biogéochimie des Ecosystèmes Forestiers, UR1138, Champenoux F-54280, France \\ ${ }^{\mathrm{b}}$ Université de Lorraine, Ecologie et Ecophysiologie Forestières, UMR1137, Vandoeuvre Les Nancy F-54500, France \\ ' INRA, Ecologie et Ecophysiologie Forestières, UMR1137, Champenoux F-54280, France \\ ${ }^{\mathrm{d}}$ Zurich-Basel Plant Science Center, Department of Environmental Sciences, Botany, University of Basel, Basel CH-4056, Switzerland \\ ${ }^{\mathrm{e}}$ Royal Netherlands Institute for Sea Research (NIOZ), Korringaweg 7, 4401 NT Yerseke, the Netherlands \\ ${ }^{\mathrm{f}}$ Centre de Recherche sur la Durabilité et la Productivité des Plantations Industrielles, BP 1291 Pointe-Noire, People's Republic of Congo \\ ${ }^{\mathrm{g}}$ CIRAD, UMR EcoE'Sols, Ecologie Fonctionnelle E' Biogéochimie des Sols E' Agro-écosystèmes, F-34060 Montpellier, France
}

\section{A R T I C L E I N F O}

\section{Article history:}

Received 18 December 2013

Received in revised form

25 April 2014

Accepted 29 April 2014

Available online 17 May 2014

\section{Keywords:}

Priming effect

Triggering

Soil organic matter destabilisation

Stable isotope spectroscopy

PLFA

Biolog test

\begin{abstract}
A B S T R A C T
Input of organic matter to soil may stimulate microbial activity and alter soil carbon storage by modifying the mineralization of native soil organic carbon (SOC). Assessing the age of SOC affected by the altered mineralization is a major challenge as the destabilisation of old SOC would be much more damageable for the overall carbon budget than the mobilization of recent SOC.

Here, we investigated the microbial populations sequentially activated after the addition of a labile substrate. We questioned whether they have distinct metabolic potential and we characterised the age of the native SOC they primed. We used soils from Congolese Eucalyptus plantations that were previously under savannah and which old and recent SOC exhibited different $\delta^{13} \mathrm{C}$. Soils were amended with glucose, in an amount sufficient to induce microbe growth, and incubated for one week. The $\delta^{13} \mathrm{C}$ of respired $\mathrm{CO}_{2}$ was continuously recorded using a tuneable diode laser spectrometer (TDLS). The combination of two glucose treatments with different $\delta^{13} \mathrm{C}$ signatures allowed partitioning the various sources of $\mathrm{CO}_{2}$ over time (recent $\mathrm{SOC}$, old $\mathrm{SOC}$ and glucose). This was combined with phospholipids fatty acids (PLFA) analyses and potential metabolic activities measurements after $40 \mathrm{~h}$ and seven days of incubation.

A peak of glucose mineralization occurred after $17 \mathrm{~h}$ of incubation. Before this peak (Stage 1), some specific communities with a strong feeding preference for recent SOC were activated. After the glucose peak (Stage 2), over-mineralization of native SOC occurred for some days. The recent C3 SOC was first preferentially used (Stage 3), while the old C4 SOC was destabilised in a later stage (Stage 4). Metabolic functions and composition of microbial communities also differed between Stages 3 and 4. Microbial populations collected at Stage 4 were slower compared to Stage 3, but more efficient in decomposing nutrient-containing substrates. Gram negative bacteria (16:1w7c and 18:1w7c) were stimulated at Stage 3 only, while Gram negative bacteria (cy17:0) were stimulated at both Stages 3 and 4 .

Our results demonstrated that the input of labile substrate alters the microbial community composition, potential metabolic activities, and the SOC pools utilisation. They pointed out the necessity to assess the age of destabilised SOC when investigating the impact of priming on carbon storage in soil.
\end{abstract}

(c) 2014 Elsevier Ltd. All rights reserved.

\footnotetext{
* Corresponding author. Tel.: +33 383394146. E-mail address: delphine.derrien@nancy.inra.fr (D. Derrien).

1 Both authors equally contributed.
}

\section{Introduction}

Agricultural practices favouring the return of plant residues to soil are recommended by the International Panel for Climate Change (IPCC, 2004) as a means to mitigate the raise of atmospheric carbon (C) responsible for climate change. Indeed it is generally 
admitted that the additional input of fresh organic matter increases soil C stocks (Lal, 2005), and improves soil fertility through the release of nutrients from the additional input. In turn, this also increases primary production and $C$ sequestration in plant biomass (Versini et al., 2013). However, the entrance of easily mobilizable organic substrates, (i.e. glucose, cellulose) into the soil can temporary activate diverse microbial populations and affect the cycling of soil organic carbon (SOC) (Kuzyakov, 2010). Such effect could be especially harmful to the environment and opposite to the expected goal when SOC is over-mineralized in an amount exceeding the stabilisation of the added substrate, but also if stable SOC is destabilised.

The short-term change in SOC dynamics induced by adding a substrate is called "priming effect" (PE) (Löhnis, 1926). Two types of $\mathrm{PE}$ occur within a temporal sequence. The first type of PE is an early phenomenon called "apparent priming effect" occurring during the first hours after the substrate addition (Blagodatkaya and Kuzyakov, 2008). Dormant and potentially active microorganisms are triggered: they accelerate their metabolism by mineralizing their storage compounds (de Nobili et al., 2001). The activity of the triggered microbial populations stops quickly when the energy provided by the added substrate is insufficient to synthesize enzymes and to grow. If the degradation of the added substrate allows enzymes production, the second type of PE called "real priming effect" is induced. The real priming effect is negative when the activated microorganisms mobilize the added substrate only. In this case, the mineralization of SOC temporary decreases until the complete consumption of the preferred substrate. In contrast, the real priming effect is positive when the activated microorganisms mineralise both the SOC and the added substrate.

A theory developed by Fontaine and coauthors in 2003 received a favourable echo in the soil science community. They hypothesized that the increase of SOC mineralization after labile substrate addition involves the succession of different microbial communities. The labile substrate favours the activity and development of fast growing microbes, called r-strategists, compared to slow growing microbes called K-strategists. After labile substrate consumption, the r-strategists may prolong their activity by using labile SOC for a few days. In the meanwhile, the K-strategists that benefit from rstrategist necromass or hydrolysis sub-products are slowly activated. They display enzymes necessary to mineralise complex compounds and are responsible for enhanced mineralization of recalcitrant $\mathrm{SOC}$

The hypothesis of Fontaine et al. (2003) has not been fully validated yet. Some changes in the structure of microbial populations have been shown after the addition of substrate (e.g. Nottingham et al., 2009; Bird et al., 2011; Dungait et al., 2011). However most studies only permitted to identify two sources for the mineralised $\mathrm{CO}_{2}$ : the added substrate and the native SOC. No distinction was made between the relative contributions of old recalcitrant and recent labile sources in the overmineralization of native SOC in spite of their importance for the overall $C$ balance. Only few studies were designed to identify more than two $\mathrm{CO}_{2}$ sources (Kuzyakov and Bol, 2004; Blagodatskaya et al., 2011, 2014), but they did not focused on the temporal evolution of these SOC sources.

In our study we tested the hypothesis that glucose addition destabilizes old SOC by sequentially activating different microbial populations, the first ones feeding on recent labile SOC and the second ones on old recalcitrant SOC. Here, we applied a glucose solution on soils sampled from two adjacent C3 Eucalyptus plantations afforested on a former C4 savannah. The isotopic composition of $\mathrm{CO}_{2}$ released from the soil was recorded with a high temporal resolution (every $30 \mathrm{~min}$ ) using isotope infrared spectroscopy to determine the relative contribution of $\mathrm{CO}_{2}$ sources. The combination of two glucose treatments with different $\delta^{13} \mathrm{C}$ signatures allowed partitioning the various sources of $\mathrm{CO}_{2}$ over time (recent C3 SOC, old C4 SOC and glucose). To relate changes of $\mathrm{CO}_{2}$ sources with functional changes of microbial populations, we also measured phospholipid fatty acid (PLFA) known as biomarker of microbial communities (Amelung et al., 2008), and we determined metabolic profiles of microorganisms using Biolog EcoPlates.

\section{Materials and methods}

\subsection{Soil samples}

The studied sites are two Eucalyptus plantations established on a native savannah at the experimental station of Kondi (CRDPI CIRAD) in Congo ( $\left.4^{\circ} 35^{\prime} \mathrm{S}, 11^{\circ} 75^{\prime} \mathrm{E}\right)$. Mean air temperature is $25^{\circ} \mathrm{C}$ with very low seasonal variations. Annual precipitations average $1200 \mathrm{~mm}$ with a dry season from mid-May to end of September. The soil is a Ferralic Arenosol (FAO) containing more than $80 \%$ of sand. Two adjacent plots of a native savannah were planted with Eucalyptus. Plot 1 was planted with the clone PF1 1-41 (density of 530 trees per hectare) in January 1992, harvested and afforested a second time in 2001 with the most commonly used hybrid in Congo (E. urophylla $\times$ E. grandis, clone UG 18-52; density of 800 trees per hectare). Plot 2 was afforested in 2001 with the Eucalyptus clone PF1 1-41 (density of 530 trees per hectare). The starter fertilization at the afforestation of the native savannah in 1992 or 2001 was: $10.3 \mathrm{~kg} \mathrm{ha}^{-1}$ of $\mathrm{N}, 10.3 \mathrm{~kg} \mathrm{ha}^{-1}$ of $\mathrm{P}$ and $16.7 \mathrm{~kg} \mathrm{ha}^{-1}$ of $\mathrm{K}$. For the second rotation of Plot 1 in 2001, $43.2 \mathrm{~kg} \mathrm{~N} \mathrm{ha}^{-1}$ were also added. Despite low SOC and nitrogen contents (Table 1 ), the mean primary production over a 7-year rotation is about $20 \mathrm{~m}^{3} \mathrm{ha}^{-1} \mathrm{yr}^{-1}$ for the clone PF1 1-41 and $30 \mathrm{~m}^{3} \mathrm{ha}^{-1} \mathrm{yr}^{-1}$ for the UG 18-52 clone.

The first five centimetres of the mineral soil were collected in December 2008, after almost 17 years and 7 years of afforestation with Eucalyptus growing in Plot 1 and Plot 2, respectively. The collected soils were named accordingly $17 \mathrm{yr}$ Euca soil (Plot 1) and 7 yr Euca soil (Plot 2). 7 yr Euca soil was less enriched in recent C3 SOC $\left(\delta^{13} \mathrm{C}=-19.2 \%\right.$ ) compared to 17 yr Euca soil $\left(\delta^{13} \mathrm{C}=-23.7 \%\right)$ as a direct consequence of the time elapsed since the conversion of savannah into Eucalyptus plantation (Table 1).

\subsection{Soil incubation}

The $7 \mathrm{yr}$ and the $17 \mathrm{yr}$ Euca soils were air-dried after sampling, sieved $(<4 \mathrm{~mm})$ and pre-incubated at $20{ }^{\circ} \mathrm{C}$ and $11.5 \%$ moisture content for six weeks. The isotopic composition of the $\mathrm{CO}_{2}$ was promptly measured during the preincubation period (see below for method description). It was $-24.7 \%$ and of $-26.7 \%$ for the $7 \mathrm{yr}$ and 17 yr Euca soil, respectively. This illustrated that the recent C3 SOC contributed more to the respiration than the old C4 SOC (65\%-70\% in the $7 \mathrm{yr}$ Euca soil, and $80-85 \%$ in the $17 \mathrm{yr}$ Euca soil - values depending on the choice of $\mathrm{C} 3$ and $\mathrm{C} 4$ end-members for the linear mixing model). Subsequently, any increment in the low flux of C4 $\mathrm{CO}_{2}$ will induced a larger shift in $\mathrm{CO}_{2}-\delta^{13} \mathrm{C}$ than the same increment

Table 1

Characteristics of soil samples collected in the $0-5 \mathrm{~cm}$ horizon. *Data from Epron et al., 2009.

\begin{tabular}{lllll}
\hline Soil & $\begin{array}{l}\text { Time since } \\
\text { afforestation } \\
\text { years }\end{array}$ & $\begin{array}{l}\text { C-content } \\
\mathrm{g} \mathrm{kg}^{-1}\end{array}$ & $\delta^{13} \mathrm{C} \%$ & $\begin{array}{l}\mathrm{N} \text {-content } \\
\mathrm{g} \mathrm{kg}^{-1}\end{array}$ \\
\hline 7 yr Euca Soil & 7 & $5.9 \pm 0.4$ & $-19.2 \pm 0.5$ & $0.38 \pm 0.01$ \\
17 yr Euca Soil & $\begin{array}{l}17 \text {, two } \\
\text { rotations }\end{array}$ & $9.2 \pm 0.5$ & $-23.7 \pm 0.1$ & $0.52 \pm 0.02$ \\
Native savannah & - & $5.7 \pm 0.7$ & $-14.8 \pm 0.3^{*}$ & $0.36 \pm 0.07$ \\
\hline
\end{tabular}


in the high flux of $\mathrm{C}_{3} \mathrm{CO}_{2}$. The effect will be more pronounced in the 17 yr Euca soil where C4-SOC respiration is very low. For this reason, we expect $\mathrm{C} 4$ priming to be more easily detected in $17 \mathrm{yr}$ Euca soil and $\mathrm{C} 3$ priming in 7 yr Euca soils.

The pre-incubated soils were poured in flat containers and sprayed with a glucose solution ( $\left.200 \mu \mathrm{g} \mathrm{C} \mathrm{g} \mathrm{soil}{ }^{-1}\right)$ or with distilled water (control treatment) (Fig. 1). The raise in moisture content was only $1 \%$ to avoid any pulse of respiration due to soil rewetting (Meisner et al., 2013). The amount of added glucose C slightly higher than the soil microbial C (from 60 to $130 \mu \mathrm{g} \mathrm{C} \mathrm{g} \mathrm{soil}{ }^{-1}$ (Versini et al., 2014)) was expected to stimulate microbial growth and to induce a real priming effect (Blagodatskaya et al., 2007; Blagodatskaya and Kuzyakov, 2008). Each soil was submitted to two different glucose treatments: a "13 $\mathrm{C}$-enriched-glucose" addition (glucose $\delta^{13} \mathrm{C}=-9.8 \%$ - Sigma, France) and a "normalglucose" addition (the $\delta^{13} \mathrm{C}$ of glucose equals the $\delta^{13} \mathrm{C}$ of $\mathrm{CO}_{2}$ measured during the preincubation period). The "normal glucose" substrates were obtained by mixing the glucose product at $-9.8 \%$ with another glucose product at $-26.7 \%$ (Groningen University, The Netherlands). As demonstrated by Kuzyakov and Bol (2004), the decomposition of glucose was completely independent on its isotopic composition. The combination of the ${ }^{113} \mathrm{C}$-enrichedglucose" and "normal-glucose" treatments allowed partitioning the various sources of $\mathrm{CO}_{2}$. In addition, the continuous recording of the $\mathrm{CO}_{2}-\delta^{13} \mathrm{C}$ shifts in the "normal-glucose" modality (see method description below) provided some insights in the sources of native SOC affected by the priming effect and was useful to define sampling dates for microbial analyses while the experiment was running. Indeed, the $\delta^{13} \mathrm{C}$ signature of the $\mathrm{CO}_{2}$ released by the mineralization of the normal-glucose substrate was expected to only slightly mask the changes in signature of the $\mathrm{CO}_{2}-\delta^{13} \mathrm{C}$ released from native SOC.

The amended soil was finally mixed, sieved $(<4 \mathrm{~mm})$ and distributed in 21 -jars ( $1 \mathrm{~kg}$ dry soil per jar). Incubations were performed in triplicate at $25{ }^{\circ} \mathrm{C}$ for one week. After $40 \mathrm{~h}$ and 7 days of incubation $30 \mathrm{~g}$ of dry soil were collected from each jar using a corer $(1 \mathrm{~cm} \varnothing)$ to perform enzymatic tests and PLFA analyses.

\subsection{PLFA analyses}

The soil microbial community was characterized by phospholipids fatty acids (PLFA) (Amelung et al., 2008). Lipids were extracted from $4 \mathrm{~g}$ of freeze-dried soil by using a modified Bligh and Dyer extraction (Boschker et al., 1999). The PLFA fraction was then isolated on silica columns and derivatized to volatile fatty-acid methyl esters. Carbon content and isotopic composition of PLFA were measured by gas chromatography-isotope ratio mass spectrometry (Middelburg et al., 2000). A detailed description of the PLFA extraction procedure and analysis can be found in Boschker (2004).

Gram negative $\left(\mathrm{Gram}^{-}\right)$bacteria were tracked using some specific mono-unsaturated fatty acids $(16: 1 \omega 7 \mathrm{c}, \mathrm{i} 17: 1 \omega 7$ and $18: 1 \omega 7 \mathrm{c})$ and cyclopropyl fatty acids (cy17:0 and cy19:0) (the latter also characterizes anaerobic Gram positive bacteria, that were unexpected in our sandy soil). Gram positive $\left(\mathrm{Gram}^{+}\right)$bacteria were characterized by terminally branched saturated fatty acids (i15:0, a15:0, i16:0, i17:0 and a17:0). Within Gram $^{+}$bacteria, Actinobacteria, belonging to the phylum of Actinobacteria, were specifically identified by methyl-branching on the tenth atom of the $C$ chain (10Me16:0 and 10Me18:0). Fungi were characterized by 18:2w6c (Zelles, 1999; Amelung et al., 2008).

We tried to partition the glucose versus C3 and C4 SOC sources in PLFA, but the accuracy of the isotope measurement of PLFA in our samples (about $2 \%$ ) was too low to get significant conclusions.

\subsection{Community level physiological profiles}

We analysed the catabolic diversity of microbial populations using the Biolog method reported by Garland (1996). This technique consists of direct incubation of soil extract on Biolog microplates and provides the pattern of potential C-substrate utilisation. It is based on tetrazolium dye reduction as an indicator of sole-C-source utilization and tests 31 of the most used $C$ sources. Biolog ${ }^{\text {TM }}$ ECO plates have been used in ecological studies to estimate metabolic potential of microbial communities (Stefanowicz, 2006).

\section{7yr Euca soil \\ SOC: $\delta^{13} \mathrm{C}=-19.2 \%$ \\ $\mathrm{CO}_{2}$ (pre-incubation): $\delta^{13} \mathrm{C}=-24.7 \%$ \\ $\mathrm{C} 3$ priming better detected than on 17yr Euca soil}

\begin{tabular}{|l|}
\hline \multicolumn{1}{|c|}{$17 y r$ Euca soil } \\
SOC: $\delta^{13} \mathrm{C}=-23.7 \%$ \\
$\mathrm{CO}_{2}$ (pre-incubation): $\delta^{13} \mathrm{C}=-26.7 \%$ \\
$\mathrm{C} 4$ priming better detected than on $7 \mathrm{yr}$ Euca soil
\end{tabular}

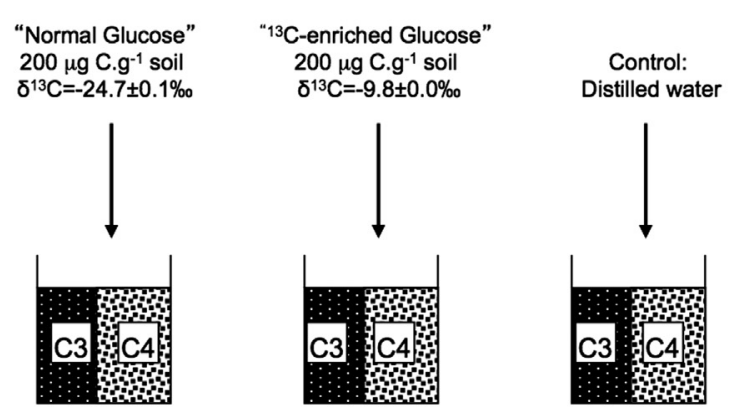

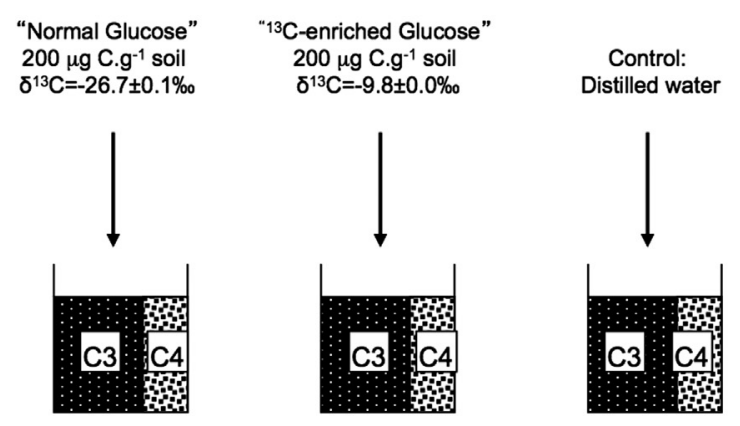

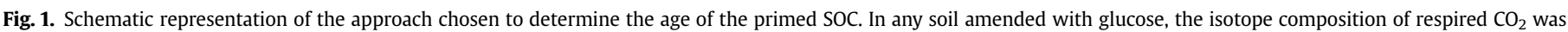

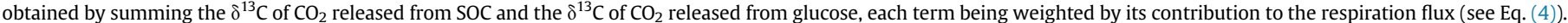

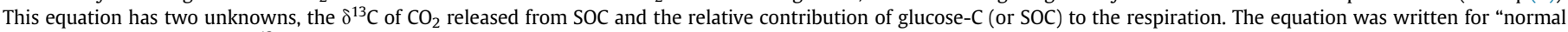

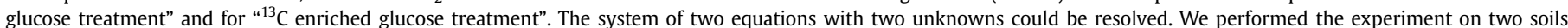

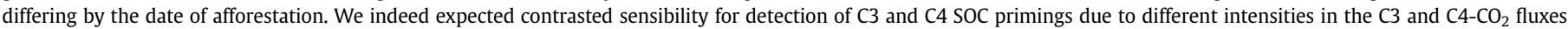
recorded during a pre-incubation. 
One gram of freshly ground soil was suspended in $10 \mathrm{ml}$ of sodium pyrophosphate $(0.1 \%)$ solution and shaken for $20 \mathrm{~min}$. Sample suspensions settled for $10 \mathrm{~min}$, were then decanted and diluted to $1 / 10$ with a $\mathrm{NaCl}$ solution ( $0.85 \%)$. Each well of Biolog plates was inoculated with $150 \mu \mathrm{l}$ of sample supernatant. Three analytical replicates were performed for each substrate. Plates were incubated at $25^{\circ} \mathrm{C}$ and the optical density was read for each plate at 16 $\mathrm{h}$ intervals over a period of $160 \mathrm{~h}$. The average well colour developments (AWCD) of the different replicates were calculated according to Garland (1996) where AWCD equals the sum of the difference between the optical density of control (no substrate) and substrate wells divided by 31 (number of substrate wells in ECO plates). AWCD 0.5 (55-h maximum slope) was also used in statistical analyses.

\subsection{Soil $\mathrm{CO}_{2}$ efflux and $\delta^{13} \mathrm{C}$}

Soil respiration and $\mathrm{CO}_{2}$ isotopic composition were determined using a Tuneable Diode Laser Spectroscopy (TDLS) (TGA100A; Campbell Scientific Inc.) coupled with a multiplexer measuring alternatively the three replicates of each treatment: control, "normal glucose" and "13 C-enriched glucose". In comparison with IRMS, laser spectroscopy has the advantage to allow automatic recording of the $\mathrm{C}$ isotopes in $\mathrm{CO}_{2}$ at a very high frequency (Bai et al., 2011). In our device each replicate was measured during one minute every $30 \mathrm{~min}$. Briefly, the diode laser produced linear wavelength scans centred on selected absorption lines of ${ }^{12} \mathrm{CO}_{2}$ and ${ }^{13} \mathrm{CO}_{2}$. The laser radiation was absorbed proportionally to the concentration of these gases in the sample cell. Three gas standard tanks were used for calibration (Air Product, $0.5 \%$ certified for $\mathrm{CO} 2$ concentrations), they were measured during one minute every five minutes (Marron et al., 2009). The ${ }^{12} \mathrm{CO} 2$ and ${ }^{13} \mathrm{CO} 2$ concentrations of the standards were respectively 297.21/3.19, 397.22/4.28 and $1189.17 / 12.83 \mu \mathrm{mol} \mathrm{mol}^{-1}$ (measurements done by PTEF-INRA Lorraine).

Total soil $\mathrm{CO} 2$ efflux $\left(\mathrm{CO}_{2}\right.$ tot $)$ and its $\delta^{13} \mathrm{C}\left(\delta^{13} \mathrm{C}_{\mathrm{CO}_{2} \text { tot }}\right)$ were calculated using the two following equations:

$\mathrm{C}_{\mathrm{CO}_{2-} \text { tot }}=\frac{\left(\left[\mathrm{CO}_{2}\right]_{\text {out }}-\left[\mathrm{CO}_{2}\right]_{\text {in }}\right) \times P \times F}{8.314 \times T \times W}$

where $\left[\mathrm{CO}_{2}\right]_{\text {in }}$ and $\left[\mathrm{CO}_{2}\right]_{\text {out }}$ are the $\mathrm{CO}_{2}$ concentrations in the incubator influx and outflux, $P$ is the atmospheric pressure, $F$ is the flow inside the bottle, $W$ is the weight of soil incubated in each bottle, $T$ is the temperature $\left({ }^{\circ} \mathrm{K}\right), 8.314 \mathrm{~J} \mathrm{~mol}^{-1}$ is the ideal gas constant.and

$\delta^{13} C_{\mathrm{CO}_{2} \text { tot }}=\frac{\frac{\left[{ }^{13} \mathrm{CO}_{2}\right]_{\text {out }}-\left[{ }^{13} \mathrm{CO}_{2}\right]_{\text {in }}}{\left[{ }^{12} \mathrm{CO}_{2}\right]_{\text {out }}-\left[{ }^{12} \mathrm{CO}_{2}\right]_{\text {in }}}}{R_{P D B}}-1$

where $\mathrm{R}$ is isotopic ratio of VPDB (0.011179602).

In order to gain in $\delta^{13} \mathrm{C}$ sensitivity in the measurement of low respiration fluxes, a tank of compressed air was used to stabilize the ${ }^{12} \mathrm{CO}_{2}$ and ${ }^{13} \mathrm{CO}_{2}$ concentrations of the incoming gas instead of using the ambient atmosphere, and the influx was set to $270 \mathrm{ml} \mathrm{min}{ }^{-1}$. Moisture content was readjusted every day to compensate the flush of air circulating in the incubators. Data were excluded when they deviated by more than $5 \%$ from a running average computed from three consecutive measurements on the same incubator (what typically happened during and after periods of incubator opening or due to instrument malfunctions).

For glucose treatments, data are given as mean and standard deviation of the one-minute measurement made on the three independent replicates.
For control treatment, as the respiration signal was low, we computed for each replicate the average values of $\mathrm{CO}_{2}$ efflux and $\delta^{13} \mathrm{C}$ and their $95 \%$ confident interval from data recorded over the whole incubation period. These averaged values were further used to determine if the SOC mineralization in amended treatments was significantly different from the SOC mineralization in the control treatments.

\subsection{Analysis of data recorded by the tuneable diode laser}

The isotopic composition of the total produced $\mathrm{CO}_{2}, \delta^{13} \mathrm{C}-$ $\mathrm{CO}_{2}$ tot, was partitioned into SOC and glucose substrate sources according to the following equation

$\delta^{13} \mathrm{C}_{\mathrm{CO}_{2-} \text { tot }}=\delta^{13} \mathrm{C}_{\mathrm{CO}_{2-} \text { glc }} \times f_{\text {glc }}+\delta^{13} \mathrm{C}_{\mathrm{CO}_{2}-\mathrm{SOC}} \times\left(1-f_{\text {glc }}\right)$

with $f_{\text {glc }}$ the fraction of $\mathrm{CO}_{2}$ efflux corresponding to glucose mineralization, $\delta^{13} \mathrm{C}_{\mathrm{CO}_{2} \text { glc }}$ the isotopic composition of the $\mathrm{CO}_{2}$ produced from glucose and $\delta^{13} \mathrm{C}_{\mathrm{CO}_{2} \mathrm{SOC}}$ the isotopic composition of the $\mathrm{CO}_{2}$ produced from SOC.

Assuming no or negligible fractionation during glucose mineralization (Ekblad et al., 2002), Eq. (3) becomes:

$\delta^{13} \mathrm{C}_{\mathrm{CO}_{2-} \text { tot }}=\delta^{13} \mathrm{C}_{\mathrm{glc}} \times f_{\mathrm{glc}}+\delta^{13} \mathrm{C}_{\mathrm{CO}_{2-} \mathrm{SOC}} \times\left(1-f_{\mathrm{glc}}\right)$

Eq. (4) written for the two modalities of glucose addition ("normal glucose", glc normal, and “" ${ }^{13}$ C-enriched glucose", glc enriched) provided a system of two equations with two unknowns, $f_{\text {glc }}$ and $\delta^{13} \mathrm{C}_{\mathrm{CO}_{2} \_\mathrm{SOC}}$ :

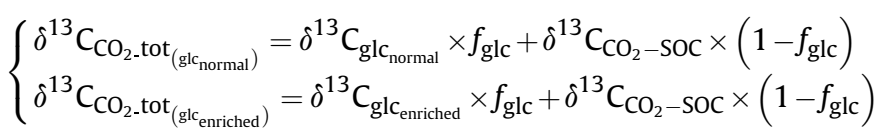

Solving the system, we get for any time:

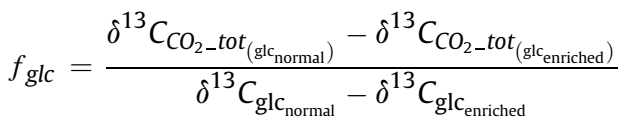

and whatever the modality of glucose addition:

$\delta^{13} \mathrm{C}_{\mathrm{CO}_{2} \text { soc }}=\frac{\delta^{13} \mathrm{C}_{\mathrm{CO}_{2-\text { tot }}}-\delta^{13} \mathrm{C}_{\mathrm{glc}} \times f_{\mathrm{glc}}}{\left(1-f_{\mathrm{glc}}\right)}$

The respiration from native $\mathrm{SOC}, \mathrm{C}_{\mathrm{CO}_{2} \mathrm{SOC}}$, was computed as follows:

$\mathrm{C}_{\mathrm{CO}_{2} \_\mathrm{SOC}}=\mathrm{C}_{\mathrm{CO}_{2} \text { tot }} \times\left(1-f_{\mathrm{glc}}\right)$

To assess the uncertainty in source partitioning, first order Taylor series approximations of the variances of $f_{\mathrm{glc}}, \delta^{13} \mathrm{C}_{\mathrm{CO}_{2} \mathrm{SOC}}$ and $\mathrm{C}_{\mathrm{CO}_{2} \mathrm{SOC}}$ were calculated using partial derivatives (Phillips and Gregg, 2001). Detailed calculations are given in Appendix:

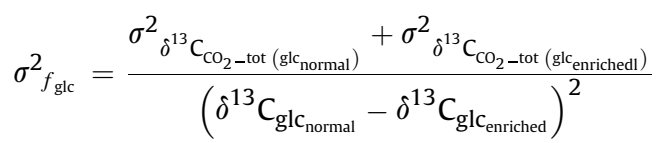




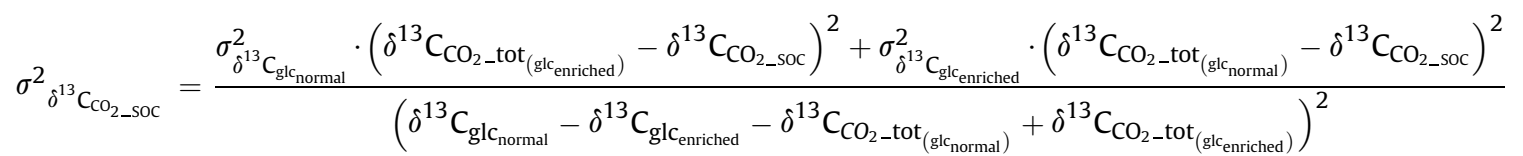

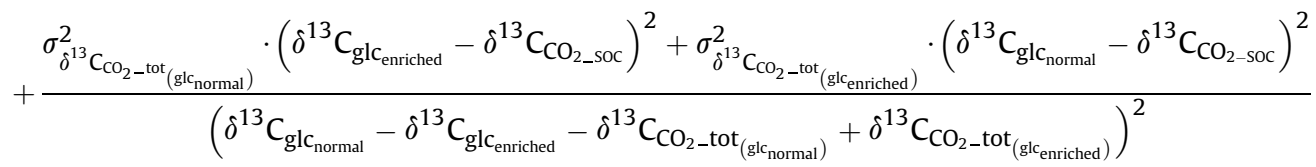

$$
\sigma^{2}{ }_{\mathrm{C}_{\mathrm{CO}_{2}-\mathrm{SOC}}}=\left(C_{\mathrm{CO}_{2}-\mathrm{tot}}\right)^{2} \times \sigma_{f_{\mathrm{glc}}}^{2}+\sigma^{2} \mathrm{C}_{\mathrm{CO}_{2}-\mathrm{tot}} \times\left(1-f_{\mathrm{glc}}\right)^{2}
$$

As the values and uncertainties for flux and $\delta^{13} \mathrm{C}$ of SOC respiration in amended treatments were not measured but derived from the resolution of equations, classical statistical tests could not be used to compare amended treatments with control treatments. We then considered that control and amended treatments were significantly different when their 95\% confidence intervals did not overlap.

\section{Results}

\subsection{Changes in $\mathrm{CO}_{2}$ efflux and isotopic composition}

Soil respiration for control treatment was about 0.12 and $0.15 \mathrm{mg} \mathrm{C} \mathrm{kg} \mathrm{soil}{ }^{-1} \mathrm{~h}^{-1}$ for $7 \mathrm{yr}$ and $17 \mathrm{yr}$ Euca soil, respectively (Table 2). Glucose addition induced a strong emission of $\mathrm{CO}_{2}$ emission $17 \mathrm{~h}$ after the incubation started (peak of $10 \mathrm{mg} \mathrm{C} \mathrm{kg} \mathrm{soil}{ }^{-1}$ $\mathrm{h}^{-1}$, Fig. 2). Respiration sharply dropped to $1 \mathrm{mg} \mathrm{C} \mathrm{kg} \mathrm{soil}{ }^{-1} \mathrm{~h}^{-1}$ after $20 \mathrm{~h}$ of incubation and continued to slightly decrease until the end of the incubation.

In the control treatments the mean $\mathrm{CO}_{2}-\delta^{13} \mathrm{C}$ was $-23.6 \%$ and $-27.0 \%$ in the $7 \mathrm{yr}$ and the $17 \mathrm{yr}$ Euca soil, respectively (Table 2). Large variations around the mean values were due to the low sensitivity of the TDLS for such low respiration. The $\mathrm{CO}_{2}-\delta^{13} \mathrm{C}$ was strongly affected by glucose addition. Signal from soils amended with " ${ }^{13} \mathrm{C}$ enriched glucose" at $-9.8 \%$ tended towards this value at the peak of $\mathrm{CO}_{2}$ emission (Fig. $2-$ top). The $\delta^{13} \mathrm{C}$ decreased after the peak, but remained above the $\delta^{13} \mathrm{C}$ of $\mathrm{CO}_{2}$ from the control soils over the 7 days of monitoring.

The $\delta^{13} \mathrm{C}$ of $\mathrm{CO}_{2}$ from soils amended with "normal-glucose" substrate showed a different pattern (Fig. 2 - bottom). Four stages were identified. Stage 1 corresponded to the first six hours of incubation during which the $\delta^{13} \mathrm{C}$ of $\mathrm{CO}_{2}$ decreased towards about $-30 \%$. In Stage 2, between $6 \mathrm{~h}$ of incubation and the peak of $\mathrm{CO}_{2}$ efflux, the isotopic composition rapidly increased to reach about the $\delta^{13} \mathrm{C}$ value of the added glucose $(-24.7 \%$ and $-26.7 \%$ for 7 and $17 \mathrm{yr}$ Euca soil, respectively), supporting the assumption of none or negligible fractionation during glucose mineralization made to convert Eq. (3) into Eq. (4). In Stage 3, after the peak and until about $50-60 \mathrm{~h}$ of incubation, the $\mathrm{CO}_{2}-\delta^{13} \mathrm{C}$ displayed lower values than the added glucose substrates. Finally, in Stage 4, after 50-60 h of incubation and until the end of the experiment, the $\mathrm{CO}_{2}-\delta^{13} \mathrm{C}$ slightly increased. It reached values similar to the $\delta^{13} \mathrm{C}$ of added glucose in $7 \mathrm{yr}$ Euca soil, and values a bit higher than the $\mathrm{CO}_{2}-\delta^{13} \mathrm{C}$ emitted from control treatment in $17 \mathrm{yr}$ Euca soil.

\subsection{Sources of emitted $\mathrm{CO}_{2}$}

The isotopic signature of $\mathrm{CO}_{2}$ was used to partition the relative contributions of glucose $\left(f_{\text {glc }}\right)$ and SOC to respiration. Calculations could only be performed after six hours of incubation, when the $\delta^{13} \mathrm{C}$ of emitted $\mathrm{CO}_{2}$ stand within the range of the $\delta^{13} \mathrm{C}$ of the two glucose substrates used as end-members in Eq. (5). The kinetics of glucose and SOC relative contributions to soil respiration were similar for the soils from the two plots. Glucose substrate strongly dominated the respiration peak. Then, the proportion of $\mathrm{CO}_{2}$ originating from glucose slightly decreased to $50 \%$ of total efflux at the end of the seven-day incubation.

The supply of glucose substantially affected the mineralization of native SOC (Fig. 3). A significant increase in the mineralization of native SOC was observed during few hours after the peak of respiration in the $7 \mathrm{yr}$ Euca soil, and during almost the whole Stage 3 in the 17 yr Euca soil. The large 95\% confidence interval for the $\mathrm{CO}_{2}$ production in $7 \mathrm{yr}$ Euca control soil (Table 2) indeed strongly reduces the significance of differences observed between control and amended treatments.

Fig. 4 displays the $\delta^{13} \mathrm{C}$ of $\mathrm{CO}_{2}$ emitted from native SOC calculated according to Eq. (6). A shift in isotopic composition towards values lower than the control treatment signature indicates a raise in the relative contribution of recent $\mathrm{C} 3$ material derived from Eucalyptus to the mineralised native SOC. Conversely, values higher than control soils demonstrate a raise in the relative contribution of old C4 material derived from savannah. As explained in the section "soil incubation" of the Material and Methods, the detection of C3 SOC priming was easier in $7 \mathrm{yr}$ Euca soil and conversely, the detection of

Table 2

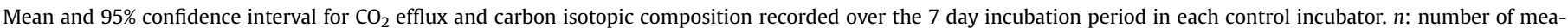

\begin{tabular}{|c|c|c|c|c|c|c|}
\hline \multirow[t]{2}{*}{ Soil } & \multirow[t]{2}{*}{ Replicate } & \multirow[t]{2}{*}{$n$} & \multicolumn{2}{|l|}{$\mathrm{CO}_{2}$ efflux } & \multicolumn{2}{|l|}{$\delta^{13} \mathrm{C}$} \\
\hline & & & Mean $\mathrm{mg} \mathrm{C} \mathrm{h}^{-1} \mathrm{~kg} \mathrm{soil}^{-1}$ & 95\% Confidence interval $\mathrm{mg} \mathrm{h}^{-1} \mathrm{~kg} \mathrm{soil}^{-1}$ & Mean \% & $95 \%$ Confidence interval \% \\
\hline \multirow[t]{3}{*}{7 yr Euca Soil } & 1 & 252 & 0.146 & {$[0.142: 0.150]$} & -21.4 & [-21.6:-21.1] \\
\hline & 2 & 241 & 0.110 & {$[0.107: 0.112]$} & -23.5 & {$[-23.8:-23.3]$} \\
\hline & 3 & 254 & 0.108 & {$[0.105: 0.112]$} & -25.8 & {$[-26.0:-25.5]$} \\
\hline \multirow[t]{3}{*}{17 yr Euca Soil } & 1 & 149 & 0.150 & {$[0.146: 0.153]$} & -26.0 & {$[-26.3:-25.7]$} \\
\hline & 2 & 114 & 0.151 & {$[0.148: 0.155]$} & -27.5 & [-27.7:-27.2] \\
\hline & 3 & 45 & 0.169 & {$[0.165: 0.173]$} & -27.4 & [-27.7:-27.1] \\
\hline
\end{tabular}
surements per replicate. 


\section{7 yr Euca soil}
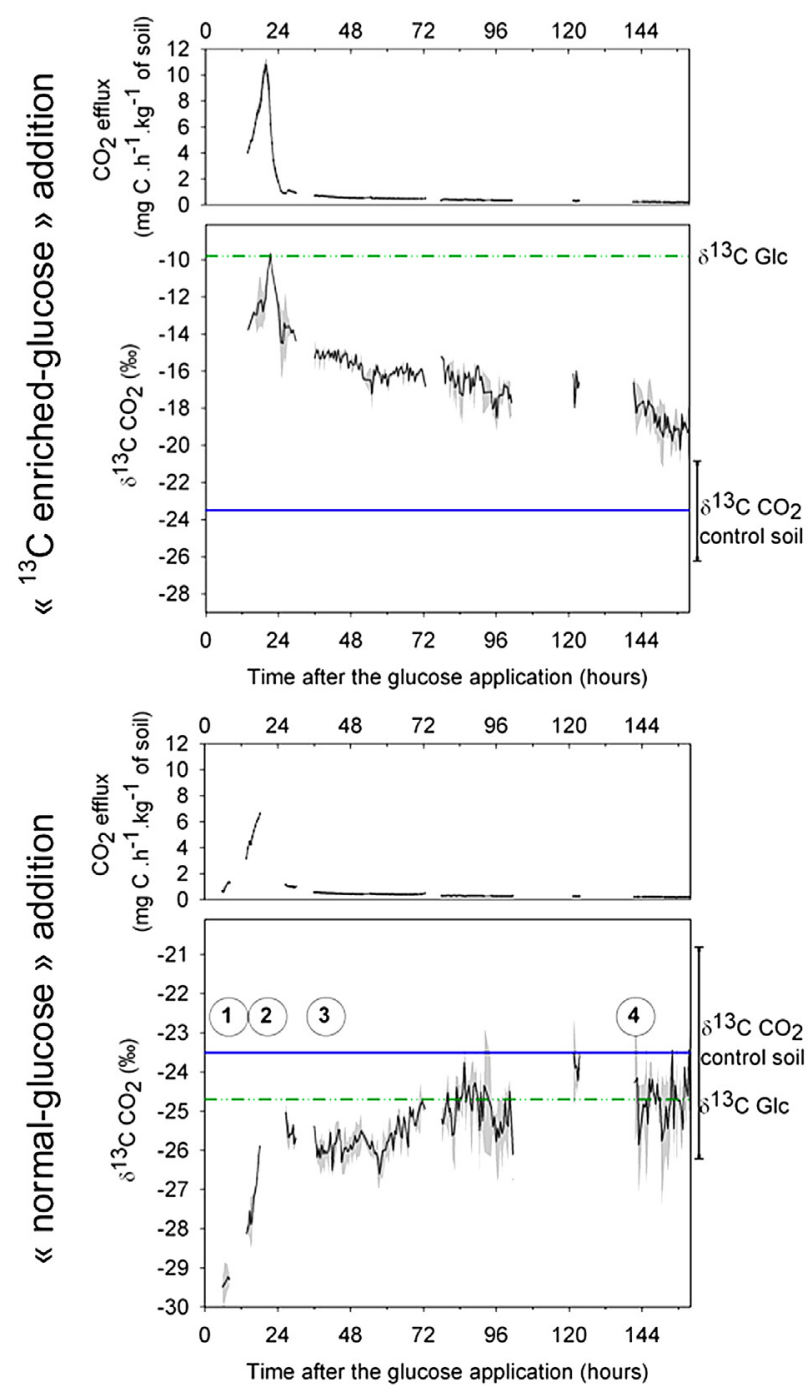

17 yr Euca soil
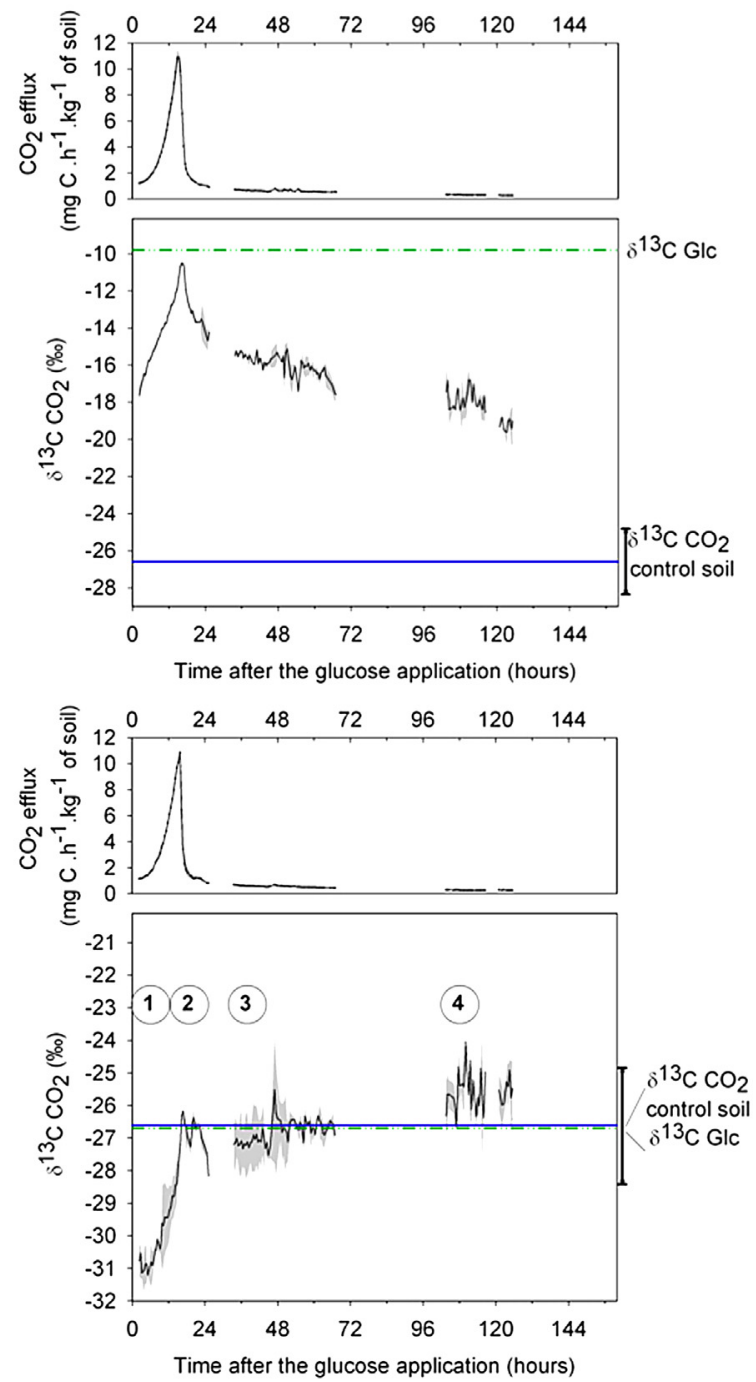

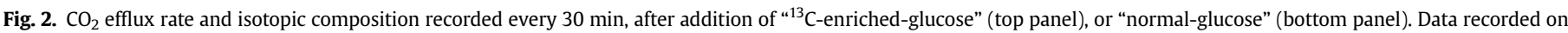

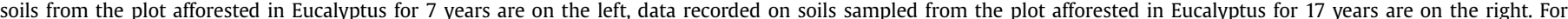

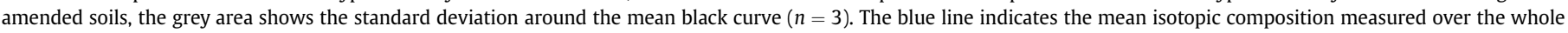

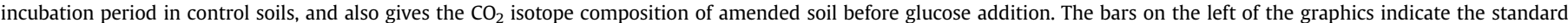

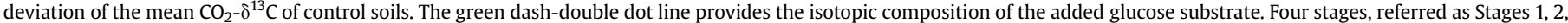

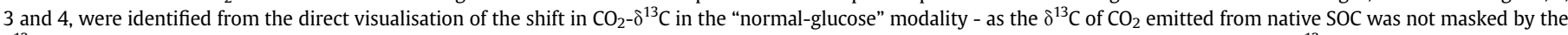

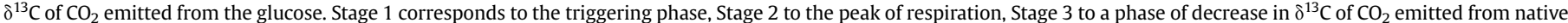
SOC compared to controls, Stage 4 to a phase of increase in $\delta^{13} \mathrm{C}$

C4 SOC priming was easier in $17 \mathrm{yr}$ Euca soil. An increase in the relative contribution of recent C3 SOC was showed in both $7 \mathrm{yr}$ and $17 \mathrm{yr}$ Euca soil amended with glucose after the peak of respiration. It was significant for $60 \mathrm{~h}$ in $7 \mathrm{yr}$ Euca soil but only for few hours in $17 \mathrm{yr}$ Euca soil. A significant raise in the relative contribution of old C4 SOC was then observed during Stage 4 in 17 yr Euca soil.

\subsection{PLFA profiles}

PLFA data were first utilised to estimate the microbial biomass (Blagodatskaya and Kuzyakov, 2013). Using the conversion factor provided by Bailey et al. (2002) who observed that $1 \mathrm{nmol}$ PLFA correspond to a flush of $2.4 \mu \mathrm{g} \mathrm{C}$ released by fumigation, and the 0.45 factor for the efficiency of the biomass extraction by fumigation (Jenkinson et al., 2004), we estimated that microbial biomass accounted for about $90 \mu \mathrm{g} \mathrm{C.g} \mathrm{soil}{ }^{-1}$ in the control treatments. In the $7 \mathrm{yr}$ Euca soil, the addition of glucose increased the PLFA by $73 \%$ at Stage 3, and $29 \%$ at stage 4 (Table 3). In the $17 \mathrm{yr}$ Euca soil, the addition of glucose increased the microbial biomass by ca $20 \%$ at both Stages 3 and 4. Analysis of individual PLFA biomarkers revealed that $\mathrm{Gram}^{-}$bacteria were strongly stimulated by glucose addition (Table 3, Fig. 5). $\mathrm{Gram}^{+}$bacteria were also stimulated during Stage 3, but only in 7 yr Euca soil. No changes were observed in PLFA specific of Actinobacteria and Fungi.

\subsection{Changes in enzymatic activity}

Effects of glucose addition on catabolic diversity of soil microbial populations were evaluated by substrate utilization patterns, using Biolog tests. Glucose addition significantly reduced the latency stage and the time to reach AWCD 0.5 whatever the stage and the soil sample (Table $4 \mathrm{a}$ ). Moreover, the latency stage and the delay to reach AWCD 0.5 were significantly lower at Stage 3 compared to Stage 4 whatever the soil sample (Table $4 a$ ). For glucose treatments, 

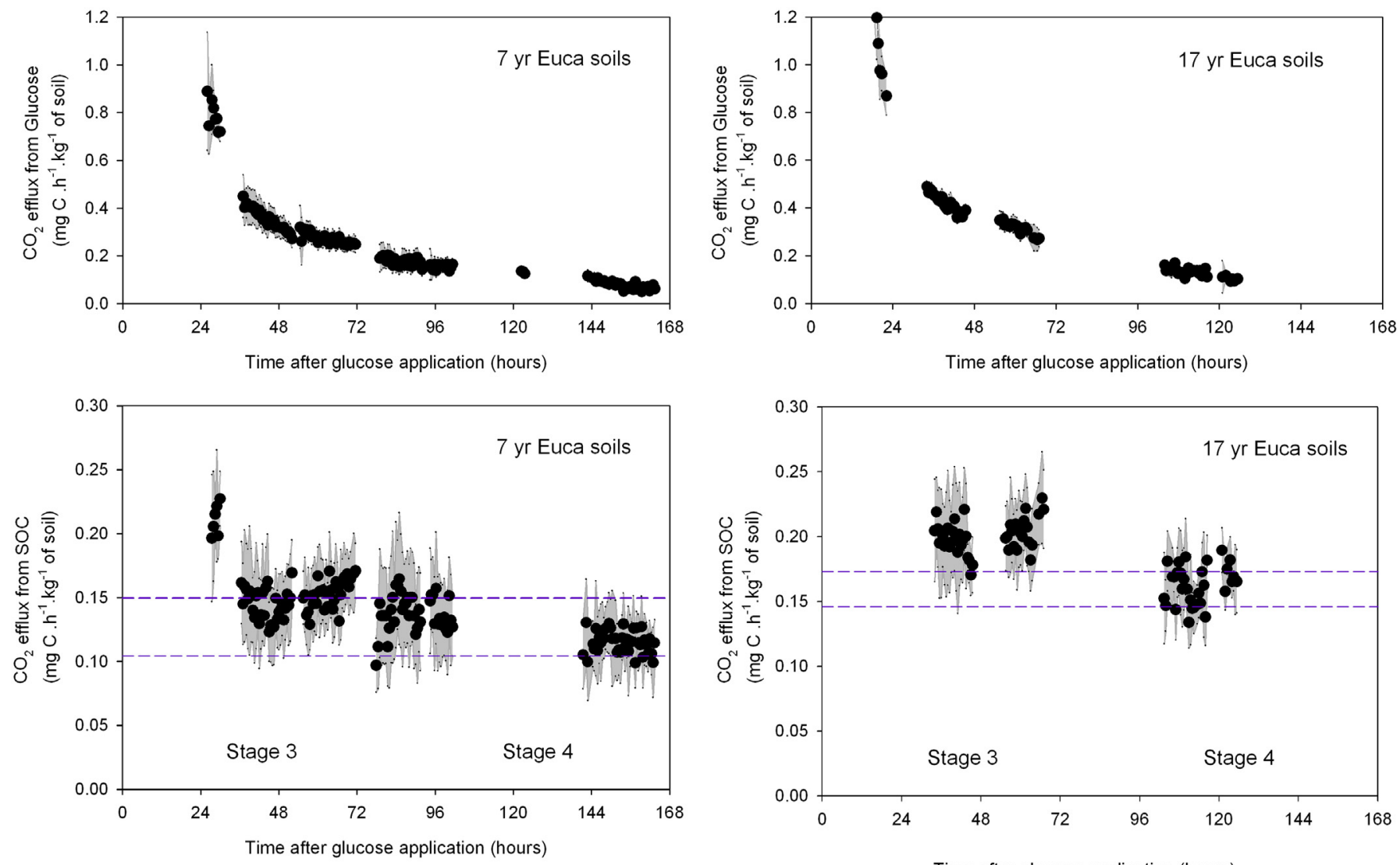

Time after glucose application (hours)

Fig. 3. $\mathrm{CO}_{2}$ produced from the incubated glucose (top panel) and of the native $\mathrm{SOC}$ (bottom panel) calculated according to Eq. (5) from data recorded every $30 \mathrm{~min}$. Results for $7 \mathrm{yr}$ Euca Soil are on the left, results for $17 \mathrm{yr}$ Euca Soil are on the right. Fluxes are presented with the associated uncertainty as a grey area (see Section 2.6). The $\mathrm{CO}_{2}$ efflux from control soil is also given on graphics showing $\mathrm{CO}_{2}$ production from native SOC, as a $95 \%$ confidence interval standing within the dashed lines.
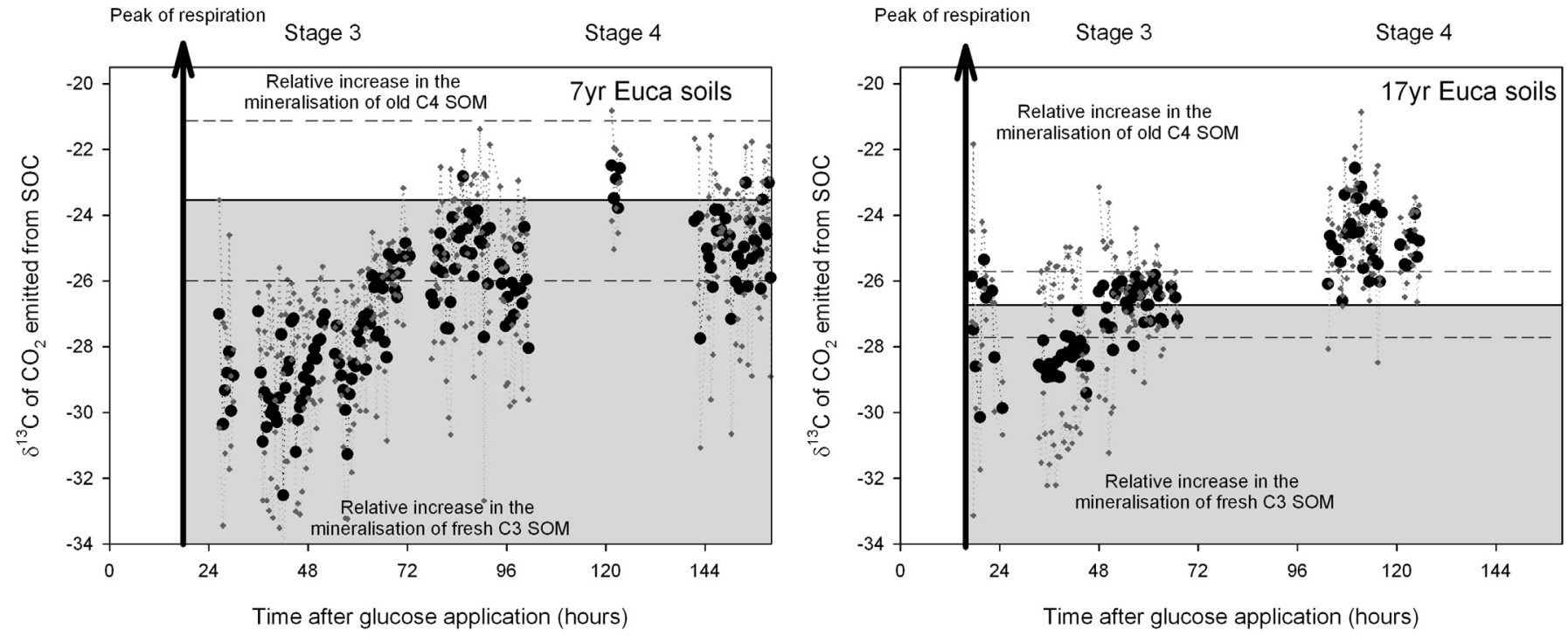

Fig. 4. Change in $\delta^{13} \mathrm{Cof} \mathrm{CO}_{2}$ emitted from native SOC after glucose addition. Dark dots stand for $\delta^{13} \mathrm{C}$ values computed from Eq. (6). Grey crosses showed the uncertainty associated with calculation as given by Eq. (9). Results for $7 \mathrm{yr}$ Euca Soil are on the left panel, for the $17 \mathrm{yr}$ Euca Soil on the right. The dark line separating the grey and white area indicates the mean $\delta^{13} \mathrm{C}$ of $\mathrm{CO}_{2}$ from control soils, and also give the $\delta^{13} \mathrm{Co} \mathrm{CO}_{2}$ from amended soil before glucose addition. The dash-lines indicate the $95 \%$ confidence interval of $\delta^{13} \mathrm{C}$ of $\mathrm{CO}_{2}$ in control soils. Any shift into the grey zone shows a relative increase in the contribution of $\mathrm{C} 3$ recent $\mathrm{C}$ to the bulk $\mathrm{SOC}$ mineralization. Conversely, any shift into the white zone shows a relative increase in the contribution of C4 old C to the bulk SOC mineralization. Control and amended treatments are significantly different in $\delta^{13} \mathrm{C}$ when the $95 \%$ confident interval of the control and the uncertainty computed for glucose treatment do not overlap. 
Table 3

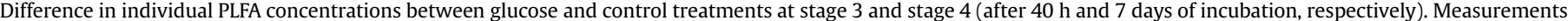

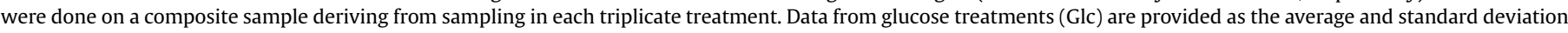
(Sd) of "normal glucose" and "enriched glucose" modalities. n.a.: non available.

\begin{tabular}{|c|c|c|c|c|c|c|c|c|c|c|c|c|c|c|c|c|}
\hline \multirow[t]{4}{*}{ Organisms } & \multicolumn{8}{|c|}{7 yr Euca soil } & \multicolumn{8}{|c|}{17 yr Euca soil } \\
\hline & \multicolumn{4}{|l|}{ Stage 3} & \multicolumn{4}{|l|}{ Stage 4} & \multicolumn{4}{|l|}{ Stage 3} & \multicolumn{4}{|l|}{ Stage 4} \\
\hline & Control & Glc & Sd & Glc & Control & Glc & Sd & Glc & Control & Glc & Sd & Glc & Control & Glc & Sd & Glc \\
\hline & \multicolumn{3}{|c|}{$\overline{(\mathrm{nmol} \mathrm{C}} \mathrm{g}^{-1}$ soil $)$} & $\%$ of control & \multicolumn{3}{|c|}{$\overline{(\mathrm{nmol} \mathrm{C}} \mathrm{g}^{-1}$ soil $)$} & $\%$ of control & \multicolumn{3}{|c|}{$\overline{(\mathrm{nmol} \mathrm{C}} \mathrm{g}^{-1}$ soil $)$} & $\%$ of control & \multicolumn{3}{|c|}{$\overline{(\mathrm{nmol} \mathrm{C}} \overline{\left.\mathrm{g}^{-1} \text { soil }\right)}$} & $\%$ of control \\
\hline Bacteria $(\mathrm{G}+)$ & 76.4 & 135.1 & 10.6 & $177 \%$ & 68.9 & 87.0 & 1.5 & $126 \%$ & 75.4 & 86.1 & 15.6 & $114 \%$ & 70.3 & 82.4 & 0.2 & $117 \%$ \\
\hline Actinobacteria & 13.1 & 13.4 & 0.8 & $102 \%$ & 12.5 & 14.2 & 1.3 & $113 \%$ & 12.0 & 12.3 & 2.5 & $103 \%$ & 11.6 & 12.9 & 0.0 & $111 \%$ \\
\hline Bacteria (G-) & 86.9 & 146.3 & 6.4 & $168 \%$ & 78.7 & 110.2 & 7.0 & $140 \%$ & 102.8 & 130.6 & 16.4 & $127 \%$ & 81.4 & 107.3 & 0.0 & $132 \%$ \\
\hline Fungi & 2.2 & 3.0 & n.a. & $139 \%$ & 0.0 & 4.0 & n.a. & n.a. & 8.9 & 8.3 & 0.1 & $93 \%$ & 6.0 & 7.0 & n.a. & $117 \%$ \\
\hline Non specific & 84.0 & 155.5 & 9.0 & $185 \%$ & 74.1 & 97.8 & 0.6 & $132 \%$ & 89.5 & 101.4 & 16.9 & $113 \%$ & 81.1 & 95.3 & 0.1 & $118 \%$ \\
\hline Total & 262.6 & 453.3 & 5.3 & $173 \%$ & 243.3 & 313.2 & 10.7 & $129 \%$ & 288.7 & 338.6 & 50.9 & $117 \%$ & 250.3 & 304.9 & 22.0 & $122 \%$ \\
\hline
\end{tabular}

microbial populations were significantly faster at Stage 4 compared to Stage 3 in degrading simple carbohydrates as well as amino acids, amines and glycerol-P, but slower in degrading polymers and carboxilic acids (Table 4b).

\section{Discussion}

\subsection{Advantages and limitations of the three sources partitioning method}

The distinction between old and recent $C$ pools affected by priming effect is a major challenge as the mobilisation of long-term preserved SOC would be much more damageable for the overall $\mathrm{C}$ budget than the mobilisation of fresh SOC. Recently, Blagotatskaya et al. (2011, 2014) successfully applied a ${ }^{14} \mathrm{C}$ labelled substrate on C3-C4 soil to disentangle old and recent SOC contributing to the over production of $\mathrm{CO}_{2}$. However the use of a radioactive substrate may require adapted laboratory facilities, depending on national regulations. We chose another approach that combined two treatments of glucose addition, with different $\delta^{13} \mathrm{C}$ signature, with the resolution of a system of equations. Compared to experiments using radioactive substrate, this approach to trace respiration sources by using stable isotopes does not require adapted laboratory facilities but faced the problems of ${ }^{13} \mathrm{C}$ fractionation and of soil $\mathrm{CO}_{2}$ admixing with atmospheric $\mathrm{CO}_{2}$, which limits data accuracy (Midwood and Millard, 2011; Pausch and Kuzyakov, 2012). The
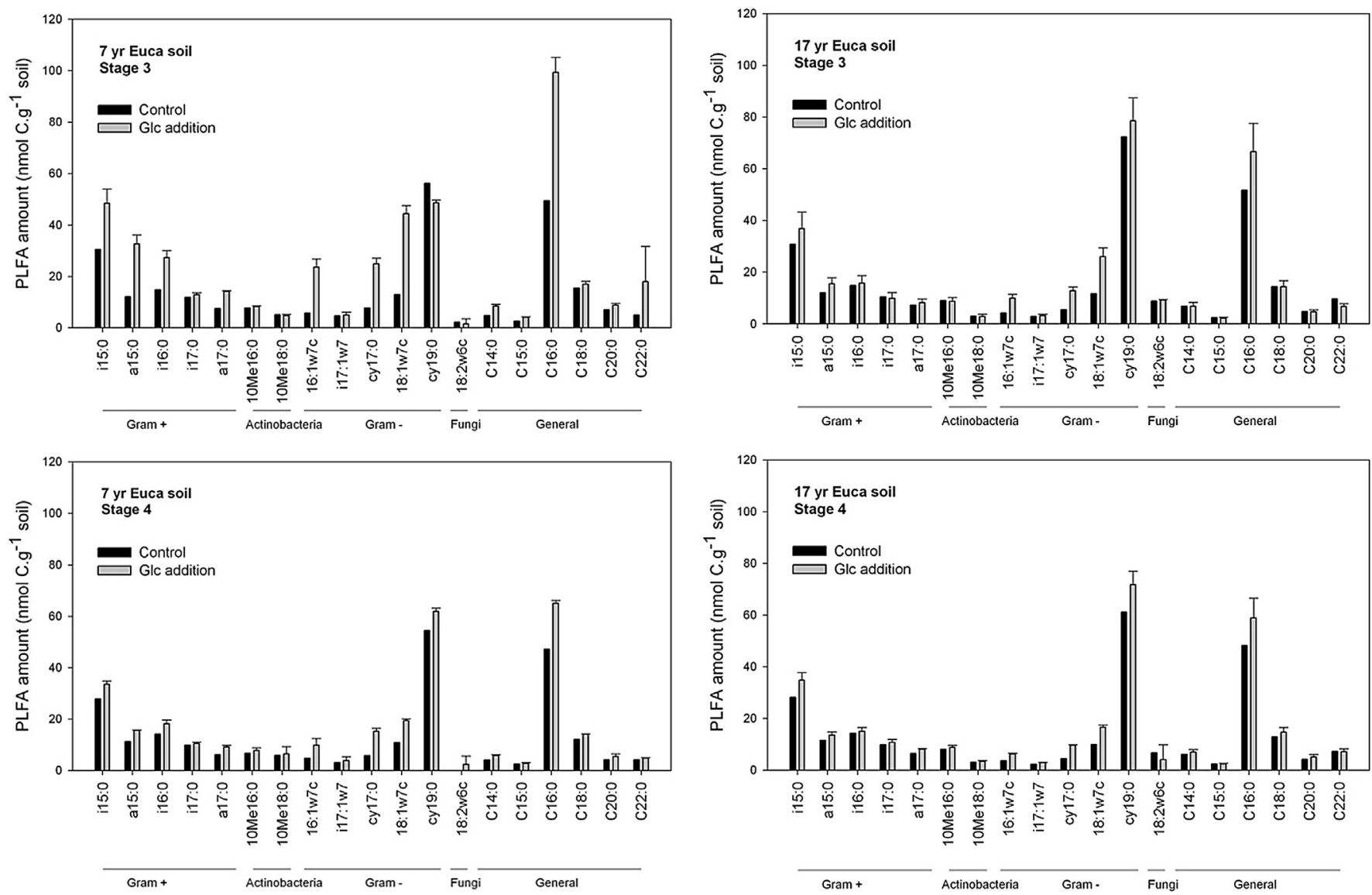

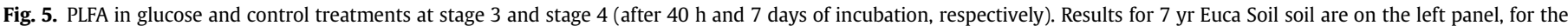

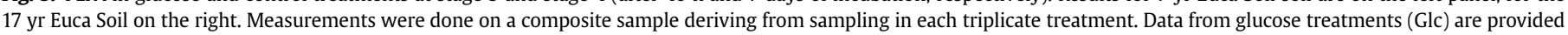
as the average and standard deviation of "normal glucose" and "enriched glucose" modalities. 
Table 4a

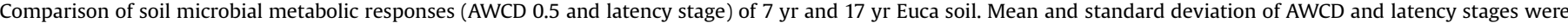

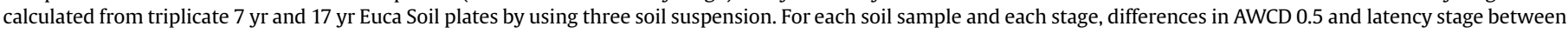
the control and glucose treatments were performed with a one-way ANOVA (Scheffe's F test). Bold values indicate a $p$-value $<0.05$.

\begin{tabular}{|c|c|c|c|c|c|c|c|c|}
\hline \multirow{3}{*}{$\begin{array}{l}\text { Soil sample } \\
\frac{\text { Stage }}{\text { Modalities }}\end{array}$} & \multicolumn{4}{|c|}{$7 \mathrm{yr}$ Euca soil } & \multicolumn{4}{|c|}{17 yr Euca soil } \\
\hline & \multicolumn{2}{|l|}{ Stage 3} & \multicolumn{2}{|l|}{ Stage 4} & \multicolumn{2}{|l|}{ Stage 3} & \multicolumn{2}{|l|}{ Stage 4} \\
\hline & Control & Glucose & Control & Glucose & Control & Glucose & Control & Glucose \\
\hline AWCD 0.5 (days) & $4.6 \pm 0.4$ & $3.0 \pm 0.1$ & $6.0 \pm 0.2$ & $3.4 \pm 0.1$ & $4.7 \pm 0.2$ & $3.0 \pm 0.2$ & $7.4 \pm 0.1$ & $3.3 \pm 0.2$ \\
\hline Latency stage (days) & $2.0 \pm 0.1$ & $1.2 \pm 0.1$ & $4.1 \pm 0.2$ & $2.1 \pm 0.2$ & $2.2 \pm 0.1$ & $1.2 \pm 0.2$ & $3.8 \pm 0.4$ & $2.1 \pm 0.2$ \\
\hline
\end{tabular}

continuous record by the TDLS of the ${ }^{12} \mathrm{CO}_{2}$ and ${ }^{13} \mathrm{CO}_{2}$ concentrations in the incoming air flushing the incubators reduced the uncertainty related to atmospheric $\mathrm{CO}_{2}$ contribution to the isotope signal. It indeed provides the atmosphere background, what a traditional IRMS cannot do. However, inevitably, the accuracy of Csources partitioning decreased over the course of our experiment, as respiration decreased. Nevertheless, we were able to determine the contribution of glucose and glucose derived metabolites to $\mathrm{CO}_{2}$ emission versus SOC contribution with less than $5 \%$ of uncertainty during the first days of the experiment, and with around $10-20 \%$ of uncertainty at the end of the incubation. The good accuracy in the isotope signature further allowed reporting significant changes in the relative contributions of recent $\mathrm{C} 3$ or old $\mathrm{C} 4$ to the mineralization of SOC. As the recent C3 SOC contributed less to the basal respiration in $7 \mathrm{yr}$ Euca soil than in $17 \mathrm{yr}$ Euca soil, the sensitivity for detecting an increase in $\mathrm{C} 3$ respiration was better in $7 \mathrm{yr}$ Euca soils, yet. Conversely, the sensitivity for detecting an increase in C4 respiration was better in $17 \mathrm{yr}$ Euca soils.

Table 4b

Substrates preferentially consumed (Biolog microplates) by soil microbial populations whatever the soil between the modalities $40 \mathrm{~h}$ (stage 3 ) and 7 days (stage 4).

\begin{tabular}{|c|c|c|c|}
\hline Substrate & & $\begin{array}{l}\text { Stage } 3 \text { vs } \\
\text { Stage } 4\end{array}$ & $p$-value \\
\hline \multirow[t]{3}{*}{ Miscellaneous } & Pyruvic Acid Methyl Ester & $=$ & 0.124 \\
\hline & Glucose-1- Phosphate & $=$ & 0.064 \\
\hline & D,L- $\alpha$-Glycerol Phosphate & $<$ & 0.039 \\
\hline \multirow[t]{4}{*}{ Polymeres } & Tween 40 & $>$ & 0.024 \\
\hline & Tween 80 & $>$ & 0.036 \\
\hline & $\alpha$-Cyclodextrin & $=$ & 0.739 \\
\hline & Glycogen & $>$ & 0.037 \\
\hline \multirow[t]{7}{*}{ Carbohydrates } & D-Cellobiose & $<$ & 0.023 \\
\hline & $\alpha$-D-Lactose & $<$ & 0.043 \\
\hline & $\beta$-Methyl-D- Glucoside & $=$ & 0.056 \\
\hline & D-Xylose & $<$ & 0.039 \\
\hline & i-Erythritol & $=$ & 0.874 \\
\hline & D-Mannitol & $<$ & 0.000 \\
\hline & N-Acetyl-D- Glucosamine & $=$ & 0.140 \\
\hline \multirow[t]{9}{*}{ Carboxilic acids } & D- Glucosaminic Acid & $>$ & 0.001 \\
\hline & D-Galactonic Acid $\gamma$-Lactone & $>$ & 0.002 \\
\hline & D- Galacturonic Acid & $=$ & 0.284 \\
\hline & 2-Hydroxy Benzoic Acid & $>$ & 0.003 \\
\hline & 4-Hydroxy Benzoic Acid & $>$ & 0.003 \\
\hline & $\gamma$-Hydroxybutyric Acid & $=$ & 0.419 \\
\hline & Itaconic Acid & $=$ & 0.294 \\
\hline & $\alpha$-Ketobutyric Acid & $=$ & 0.429 \\
\hline & D-Malic Acid & $=$ & 0.356 \\
\hline \multirow[t]{6}{*}{ Amino acids } & L-Arginine & $=$ & 0.147 \\
\hline & L-Asparagine & $<$ & 0.041 \\
\hline & L- Phenylalanine & $<$ & 0.026 \\
\hline & L-Serine & $<$ & 0.043 \\
\hline & L-Threonine & $<$ & 0.028 \\
\hline & Glycyl-L- Glutamic Acid & $=$ & 0.425 \\
\hline \multirow[t]{2}{*}{ Amines Amides } & Phenylethyl- amine & $<$ & 0.032 \\
\hline & Putrescine & $<$ & 0.029 \\
\hline
\end{tabular}

Difference in the substrates consumption between stage 3 and 4 was performed at AWCD 0.5 with a one-way ANOVA (Scheffe's F test, $n=3$ ). Bold values indicate a $p$ value $<0.05$. Legend: $=$, not significant differences; $>$ significantly more consumed at stage $3 ;<$ significantly more consumed at stage 4 .

\subsection{Evidence of triggering on microbial populations feeding on recent C3 SOC}

In our experiment, the use of a laser spectrometry offered the unique opportunity to capture changes in the respiration sources at a hour timescale (Griffis et al., 2004; Plain et al., 2009; Epron et al., 2011), while studies on priming sources traditionally collect $\mathrm{CO}_{2}$ trapped in $\mathrm{NaOH}$ vessels at a daily or weekly timescale. During Stage 1 , the mineralization of glucose had started, as demonstrated by the shift towards glucose $\delta^{13} \mathrm{C}$ in the "enriched glucose" treatment (Fig. 2), where the glucose $\delta^{13} \mathrm{C}$ clearly differed from the $\delta^{13} \mathrm{C}$ of $\mathrm{CO}_{2}$ produced in control soil. But the glucose mineralization was quite low yet. Such a lag phase in glucose mineralization was already reported in other studies and interpreted as a phase of microbe reactivation and growth (De Nobili et al., 2001; Schneckenberger et al., 2008; Zyakun et al., 2013), what was confirmed by the raise in PLFA amounts (Table 3). A strong decrease of $\delta^{13} \mathrm{C}$ of $\mathrm{CO}_{2}$ during Stage 1 was observed in the "normal-glucose" treatments (Fig. 2). In these "normal-glucose" treatments the added glucose had a $\mathrm{C}$ isotope composition similar to the $\delta^{13} \mathrm{C}$ of $\mathrm{CO}_{2}$ produced in control soil. The $\delta^{13} \mathrm{C}$ decrease resulted either (i) from a change in sources of mineralised SOC immediately after glucose addition or (ii) from isotope fractionation during glucose mineralisation. We posit that the main reason would be the preferential utilisation of the recent C3 organic matter. Not all microbes responsible for the basal respiration would be rapidly triggered by the glucose addition, but only some specific microbial populations feeding on C3 material. Zyakun et al. (2013) indeed demonstrated by measuring respiratory coefficient that the reactivation of microbes occurring rapidly after glucose addition involves the mineralization of stored lipids, known to be ${ }^{13} \mathrm{C}$ depleted. This interpretation of a sole stimulation of some microbe feeding on recent C3 SOC would be consistent with the further observation that the microbial communities active at stage 3 after the peak of glucose consumption preferentially utilise C3 SOC. If any isotope fractionation occured at Stage 1 it would be due to kinetics effect. Measurements of $\mathrm{CO}_{2} \delta^{13} \mathrm{C}$ performed at the peak of glucose consumption (Stage 2) indeed indicated that thermodynamic fractionation during glucose mineralisation was minor.

\subsection{Characteristics of microbial populations sequentially active}

The triggered populations utilised the added glucose- $\mathrm{C}$ at Stage 2 and the recent C3 SOC at Stage 3 as glucose- $C$ became rapidly included in microbial metabolites and less accessible (Derrien et al., 2007; Hill et al., 2008). At Stage 4, changes in the isotopic signature of mineralised SOC in the $17 \mathrm{yr}$ Euca soil amended with glucose indicated that the active populations preferentially mineralised the old C4 SOC. In the conditions of the Biolog test, these populations collected at Stage 4 consumed the tested substrates slower than populations from Stage 3, and interestingly they exhibited a higher potential for the decomposition of nutrient-containing substrates (Table 4a and 4b). The soils of our experiment are known to be poor in available nitrogen (Mareschal et al., 2013). We postulated that 
the populations efficient in $\mathrm{N}$ mining outcompeted the populations active at Stage 3 when available nitrogen became limiting. They found their N-resource in the old C4 SOC, old soil organic matter being $\mathrm{N}$-rich compared with recent one due to nitrogen immobilisation by microbes during decomposition (von Lützow et al., 2007). The relation between old SOC mining and $\mathrm{N}$ availability is not univocal, yet. Blagodatskaya et al. (2011) invoked the mining of old SOC to meet needs in N as we did, but Waldrop and Firestone (2004a) showed that addition of mineral N can enhanced old SOC mineralization through an increase oxidative activity. These opposite responses indicate that the enhanced mineralization of old SOC depends on the factor limiting the activity of the microbial populations, e.g. energy, nitrogen ... (Hamer and Marschner, 2005; Fontaine et al., 2011; Nottingham et al., 2012; Sullivan and Hart, 2013).

$\mathrm{Gram}^{-}$bacteria were particularly important in the response to substrate addition, as also found by other authors (Waldrop and Firestone, 2004b; Notthingham et al., 2009; Bastida et al., 2013; Dungait et al., 2013) and could be designed as r-strategists. A complementary experiment that we performed adding $200 \mu \mathrm{g} \mathrm{C}$. soil ${ }^{-1}$ of $99 \%{ }^{13} \mathrm{C}$ labelled glucose in $17 \mathrm{yr}$ Euca soil revealed that the growth of microbe was supported by glucose substrate at Stage 3 while native SOC was also included in the newly formed biomass at Stage 4 (See Supplementary). PLFA markers for $\mathrm{Gram}^{+}$bacteria experiment did not exhibit the same dynamics in the two soils of our experiment. Observations made by other groups indicate they usually do not rapidly take advantage of labile substrate addition. Waldrop and Firestone (2004b) and Bird et al. (2011) observed a response of $\mathrm{Gram}^{+}$populations several months after substrate addition whereas Bastida et al. (2013) revealed a response only delayed by few days compared to $\mathrm{Gram}^{-}$populations. In line with these priming experiments, Kramer and Gleixner (2008) demonstrated that at the steady state $\mathrm{Gram}^{-}$bacteria preferentially use recent SOC and $\mathrm{Gram}^{+}$bacteria old SOC.

\subsection{Implications of pulse-addition of labile substrates on the preservation of carbon in soil}

After seven days of incubation $50 \%$ of the glucose- $C$ was still retained in soil (ca. $100 \mu \mathrm{g} \mathrm{g}^{-1}$ of soil), largely exceeding the amount of native SOC that had been over-mineralised (ca. $10 \mu \mathrm{g} \mathrm{g}^{-1}$ of soil). At the end of the experiment it can be reasonably assumed that the glucose- $C$ was included in microbial metabolites and that in average it will be preserved over years to decades (Derrien et al., 2006). Balancing the $C$ input into the soil by the output is not sufficient to assess the soil storage potential yet. Changes in the duration of SOC storage must also be inspected. The shifts in the isotope composition of respired native SOC showed that the glucose addition induced first a destabilisation of the recent pool of native SOC for a couple of days and then a destabilisation of the old pool of native SOC (Fig. 4). The latter may seriously impact the $C$ storage in our soils. We could neither precisely determine the age of the old organics that were destabilised (apart than they were older than 7 or $17 \mathrm{yr}$ old, depending on the soil), nor determine if the destabilisation occurred for a few days or persisted over time. Even if the effect is short, it is of primary importance to consider it as pulse addition of labile substrate frequently occurs in most plant-soil systems. Pulse-inputs are typical for root exudation and breaking-down of dead microbial cells releasing soluble compounds in the rhizosphere (Kuzyakov, 2010). Soluble extracellular enzymes also scavenge substrates away from the rhizosphere and generate flush of easily available compounds. Therefore, the potential of a soil to preserve $C$ is strongly dependent on the age of the SOC utilised by microbes after sporadic but regular supply of labile substrate. Some previous studies (Blagodatskaya et al., 2008, 2011) reported that the rate of $C$ input determines the intensity of the priming: (i) low input is insufficient to induce microbe growth and solely causes a microbe biomass turnover, (ii) input in an amount similar to microbe biomass induces a positive priming - as in our experiment, (iii) while input several time higher than the microbe biomass induces a zero or negative priming due to the preferential use of the added substrate rather than SOC. Blagodatskaya et al. (2011) reported that higher biomass turnover caused by a low input only affects the recent SOC, in accordance with our observations during Stage 1 . We may also expect that despite a balance favouring $C$ sequestration, a high substrate addition may alter the duration of $\mathrm{C}$ storage. Recent SOC would be less mobilised than in normal conditions due to the great accessibility of added substrate, but a high amount of nutriments would be required, leading to a destabilisation of old SOC in nutrient-poor soil.

\section{Conclusions}

To assess the impact of pulse-addition of labile substrate on the $C$ storage in soil, the amount of preserved substrate should be compared to the over-mineralized SOC, but shifts in the age of mineralised SOC should also be investigated. Our study demonstrated that the pulse input of glucose induced major changes in microbial community structure and SOC utilisation patterns, inducing first a preferential use of recent SOC but then a destabilisation of old SOC. This study making use of TDLS to partition the native $\mathrm{SOC}$ sources of respired $\mathrm{CO}_{2}$ at a very high frequency calls for other experiments using the same kind of device, preferentially in soils with a high basal respiration so that to gain in signal sensitivity, and if possible on longer period of time.

Nutrient limitation could be responsible for the shift from recent to old SOC sources and would then exert a strong control on the duration of carbon preservation in soil. It appears crucial to verify this idea on soils with different levels of fertility.

\section{Ackowledgements}

This work was funded by the Fabelor research program (12000176A ). The UMR 1137 and the UR 1138 are supported by the French National Research Agency through the Laboratory of Excellence ARBRE (ANR-12- LABXARBRE-01). We thank the technical staff of the CR2PI for taking care over years of the C3C4 chronosequence in Congo, Jacques Ranger for helping with soil sampling, Nicolas Richet and André Clerc for technical support, Frans Stellaard for offering its C3-glucose, Mélanie Maître and Charlotte Burgault for data treatment, Jean-Paul Laclau, Rémi d'Annunzio and Louis Mareschal for discussions and the two referees for their comments. Pierre-Emmanuel Courty gratefully acknowledge the Swiss National Science Foundation (ambizione grant PZ00P3_136651). Special thoughts to Anna and Paulette.

\section{Appendix A. Supplementary data}

Supplementary data related to this article can be found at http:// dx.doi.org/10.1016/j.soilbio.2014.04.030.

\section{Appendix}

The solution (Eq. (8)) to the general Taylor series equation for the variance of $f_{\text {glc }}$ (Eq. (5)) can be determined as follows

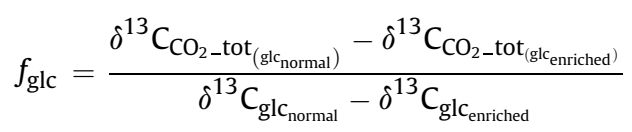


D. Derrien et al. / Soil Biology E' Biochemistry 76 (2014) 149-160

159

$\delta^{13} \mathrm{C}_{\mathrm{CO}_{2-} \text { tot }}{\text { (g lc } \mathrm{c}_{\text {normal }}}, \delta^{13} \mathrm{C}_{\mathrm{CO}_{2 \_\mathrm{N}}}$

$\delta^{13} \mathrm{C}_{\mathrm{CO}_{2-} \text { tot }}{\left.\text { (g lc } \mathrm{c}_{\text {enriched }}\right)}, \delta^{13} \mathrm{C}_{\mathrm{CO}_{2 \_\mathrm{E}}}$

$\delta^{13} \mathrm{C}_{\mathrm{glc}} \mathrm{normal}, \delta^{13} \mathrm{C}_{\mathrm{glc} \_\mathrm{N}}$

$\delta^{13} \mathrm{C}_{\mathrm{glc}} \mathrm{enriched}, \delta^{13} \mathrm{C}_{\text {glc_E }}$

The partial derivatives for $f_{\text {gl }}$ are:

$\frac{\partial f_{\text {gl }}}{\partial \delta^{13} \mathrm{C}_{\mathrm{CO}_{2} \mathrm{~N}}}=\frac{1}{\delta^{13} \mathrm{C}_{\mathrm{glc} \_\mathrm{N}}-\delta^{13} \mathrm{C}_{\mathrm{glc} \_\mathrm{E}}}$

$\frac{\partial f_{\text {gl }}}{\partial \delta^{13} \mathrm{C}_{\mathrm{CO}_{2} \_\mathrm{E}}}=\frac{-1}{\delta^{13} \mathrm{C}_{\mathrm{glc} \_\mathrm{N}}-\delta^{13} \mathrm{C}_{\mathrm{glc} \_\mathrm{E}}}$

$\frac{\partial f_{\text {gl }}}{\partial \delta^{13} \mathrm{C}_{\text {gl } \_\mathrm{N}}}=\frac{-\left(\delta^{13} \mathrm{C}_{\mathrm{CO}_{2} \_\mathrm{N}}-\delta^{13} \mathrm{C}_{\mathrm{CO}_{2} \_\mathrm{E}}\right)}{\left(\delta^{13} \mathrm{C}_{\mathrm{glc} \_\mathrm{N}}-\delta^{13} \mathrm{C}_{\mathrm{glc} \_\mathrm{E}}\right)^{2}}$

$\frac{\partial f_{\text {gl }}}{\partial \delta^{13} \mathrm{C}_{\text {gl } \_\mathrm{E}}}=\frac{\left(\delta^{13} \mathrm{C}_{\mathrm{CO}_{2} \_\mathrm{N}}-\delta^{13} \mathrm{C}_{\mathrm{CO}_{2} \_\mathrm{E}}\right)}{\left(\delta^{13} \mathrm{C}_{\text {glc_N }}-\delta^{13} \mathrm{C}_{\text {glt } \_\mathrm{E}}\right)^{2}}$

(A2)

These derivatives are substituted into

$$
\begin{aligned}
\sigma^{2} f_{\text {gl }}= & \left(\frac{\partial f_{\text {gl }}}{\partial \delta^{13} \mathrm{C}_{\mathrm{CO}_{2} \mathrm{~N}}}\right)^{2} \cdot \sigma_{\delta^{13} \mathrm{C}_{\mathrm{CO}_{2}-\mathrm{N}}}^{2}+\left(\frac{\partial f_{\text {gl }}}{\partial \delta^{13} \mathrm{C}_{\mathrm{CO}_{2} \mathrm{E}}}\right)^{2} \cdot \sigma_{\delta^{13} \mathrm{C}_{\mathrm{CO}_{2}-\mathrm{E}}}^{2} \\
& +\left(\frac{\partial f_{\text {gl }}}{\partial \delta^{13} \mathrm{C}_{\mathrm{glc} \_\mathrm{N}}}\right)^{2} \cdot \sigma_{\delta^{13} \mathrm{C}_{\mathrm{gl} \_\mathrm{N}}}^{2}+\left(\frac{\partial f_{\text {gl }}}{\partial \delta^{13} \mathrm{C}_{\text {glc_E}}}\right)^{2} \cdot \sigma_{\delta^{13} \mathrm{C}_{\mathrm{gl} \_\mathrm{E}}}^{2}
\end{aligned}
$$

to give

$$
\begin{aligned}
& \sigma^{2} f_{g l c}=\frac{\sigma_{\delta^{13} \mathrm{C}_{\mathrm{CO}_{2}-N}}^{2}+\sigma^{2} \delta^{13} \mathrm{C}_{\mathrm{CO}_{2}-E}}{\left(\delta^{13} \mathrm{C}_{g l c_{-} N}-\delta^{13} \mathrm{C}_{g l c_{-} E}\right)^{2}} \\
& +\frac{\left(\sigma^{13} C_{g l c_{-} N}+\sigma^{2} \delta^{13} C_{g l c_{-} E}\right) \cdot\left(\delta^{13} \mathrm{C}_{\mathrm{CO}_{2-} \mathrm{N}}-\delta^{13} \mathrm{C}_{\mathrm{CO}_{2-} E}\right)^{2}}{\left(\delta^{13} \mathrm{C}_{g l c_{-} N}-\delta^{13} \mathrm{C}_{g l c_{-} E}\right)^{4}}
\end{aligned}
$$

This equation can be approximated by

$$
\sigma^{2} f_{\text {gl }}=\frac{\sigma_{\delta^{13} \mathrm{C}_{\mathrm{CO}_{2}-\mathrm{N}}}^{2}+\sigma_{\delta^{13} \mathrm{C}_{\mathrm{CO}_{2} \mathrm{E}}}^{2}}{\left(\delta^{13} \mathrm{C}_{\mathrm{glc} \_\mathrm{N}}-\delta^{13} \mathrm{C}_{\mathrm{glc} \_\mathrm{E}}\right)^{2}}
$$

Similarly, the solution (Eq. (9)) to the general Taylor series equation for the variance of $\partial^{13} \mathrm{C}_{\mathrm{CO}_{2} \text { SOC }}$ (Eq. (6)) can be determine as follows:

For the normal glucose modality, we have

$\delta^{13} \mathrm{C}_{\mathrm{CO}_{2-\mathrm{SOC}}}=\frac{\delta^{13} \mathrm{C}_{\mathrm{CO}_{2} \mathrm{~N}}-\delta^{13} \mathrm{C}_{\text {glt } \_\mathrm{N}} \times f_{\text {gl }}}{\left(1-f_{\text {gl }}\right)}$

with $f_{\text {gl }}=\frac{\delta^{13} \mathrm{C}_{\mathrm{CO}_{2}-\mathrm{N}}-\delta^{13} \mathrm{C}_{\mathrm{CO}_{2} \mathrm{E}}}{\delta^{13} \mathrm{C}_{\text {gl c } \_\mathrm{N}}-\delta^{13} \mathrm{C}_{\text {gl_ } \_\mathrm{E}}}$

Eq. (A6) can also be written as

$\delta^{13} \mathrm{C}_{\mathrm{CO}_{2-} \text { Soc }}=\frac{\delta^{13} \mathrm{C}_{\mathrm{glc} \_\mathrm{N}} \times \delta^{13} \mathrm{C}_{\mathrm{CO}_{2 \_} \mathrm{E}}-\delta^{13} \mathrm{C}_{\mathrm{glc} \_\mathrm{E}} \times \delta^{13} \mathrm{C}_{\mathrm{CO}_{2 \_} \mathrm{N}}}{\delta^{13} \mathrm{C}_{\mathrm{glc} \_\mathrm{N}}-\delta^{13} \mathrm{C}_{\mathrm{glc} \_\mathrm{E}}-\delta^{13} \mathrm{C}_{\mathrm{CO}_{2} \_\mathrm{N}}+\delta^{13} \mathrm{C}_{\mathrm{CO}_{2 \_} \mathrm{E}}}$

Let's denote

$\alpha=\delta{ }^{13} C_{g l c_{-} N} \times \delta^{13} C_{C_{2_{-} E}}-\delta^{13} C_{g l c_{-} E} \times \delta^{13} C_{C_{O_{-}} N}$

$\beta=\delta^{13} C_{g l c_{-} N}-\delta^{13} C_{g l c_{-} E}-\delta^{13} C_{C_{2-} N}+\delta^{13} C_{C_{O_{2}} E}$

The partial derivatives for $\partial^{13} \mathrm{C}_{\mathrm{CO}_{2} \_} \mathrm{SOC}$ are:

$\frac{\partial \delta^{13} \mathrm{C}_{\mathrm{CO}_{2-\text { Soc }}}}{\partial \delta^{13} \mathrm{C}_{\text {glc_N }}}=\frac{\beta . \delta^{13} \mathrm{C}_{\mathrm{CO}_{2 \_} \mathrm{E}}-\alpha}{\beta^{2}}=\frac{\delta^{13} \mathrm{C}_{\mathrm{CO}_{2-} \mathrm{E}}-\delta^{13} \mathrm{C}_{\mathrm{CO}_{2-S O C}}}{\beta}$

$\frac{\partial \delta^{13} \mathrm{C}_{\mathrm{CO}_{2-\mathrm{SOC}}}}{\partial \delta^{13} \mathrm{C}_{\mathrm{glc} \_\mathrm{E}}}=\frac{-\beta . \delta^{13} \mathrm{C}_{\mathrm{CO}_{2 \_} \mathrm{N}}+\alpha}{\beta^{2}}=-\frac{\delta^{13} \mathrm{C}_{\mathrm{CO}_{2-} \mathrm{N}}-\delta^{13} \mathrm{C}_{\mathrm{CO}_{2-\mathrm{SOC}}}}{\beta}$

$\frac{\partial \delta^{13} \mathrm{C}_{\mathrm{CO}_{2-\mathrm{SOC}}}}{\partial \delta^{13} \mathrm{C}_{\mathrm{CO}_{2 \_} \mathrm{N}}}=\frac{-\beta . \delta^{13} \mathrm{C}_{\mathrm{glc} \_\mathrm{E}}+\alpha}{\beta^{2}}=-\frac{\delta^{13} \mathrm{C}_{\mathrm{glc} \_\mathrm{E}}-\delta^{13} \mathrm{C}_{\mathrm{CO}_{2 \_-\mathrm{SOC}}}}{\beta}$

$\frac{\partial \delta^{13} \mathrm{C}_{\mathrm{CO}_{2 \_} \mathrm{SOC}}}{\partial \delta^{13} \mathrm{C}_{\mathrm{CO}_{2} \mathrm{E}}}=\frac{\beta . \delta^{13} \mathrm{C}_{\mathrm{glc} \_\mathrm{N}}-\alpha}{\beta^{2}}=\frac{\delta^{13} \mathrm{C}_{\mathrm{glc} \_\mathrm{N}}-\delta^{13} \mathrm{C}_{\mathrm{CO}_{2-\mathrm{SOC}}}}{\beta}$

These derivatives are substituted into

$$
\begin{aligned}
& \sigma^{2} \delta^{13} C_{C_{2}-S O C}=\left(\frac{\partial \delta^{13} C_{C_{2-S O C}}}{\partial \delta^{13} C_{g l C_{-} N}}\right)^{2} \cdot \sigma_{\delta^{13} C_{g l \_\_N}}^{2}+\left(\frac{\partial \delta^{13} C_{\mathrm{CO}_{2-S O C}}}{\partial \delta^{13} C_{\text {gl } \_ \text {E }}}\right)^{2} \\
& \cdot \sigma_{\delta^{13} \mathrm{C}_{\mathrm{gl} \_\mathrm{E}}}^{2}+\left(\frac{\partial \delta^{13} \mathrm{C}_{\mathrm{CO}_{2-\mathrm{SOC}}}}{\partial \delta^{13} \mathrm{C}_{\mathrm{CO}_{2 \_} \mathrm{N}}}\right)^{2} \cdot \sigma^{2} \delta^{13} \mathrm{C}_{\mathrm{CO}_{2} \mathrm{~N}} \\
& +\left(\frac{\partial \delta^{13} \mathrm{C}_{\mathrm{CO}_{2-\mathrm{SOC}}}}{\partial \delta^{13} \mathrm{C}_{\mathrm{CO}_{2 \_} \mathrm{E}}}\right)^{2} \cdot \sigma_{\delta^{13} \mathrm{C}_{\mathrm{CO}_{2} \mathrm{E}}}^{2}
\end{aligned}
$$

to give

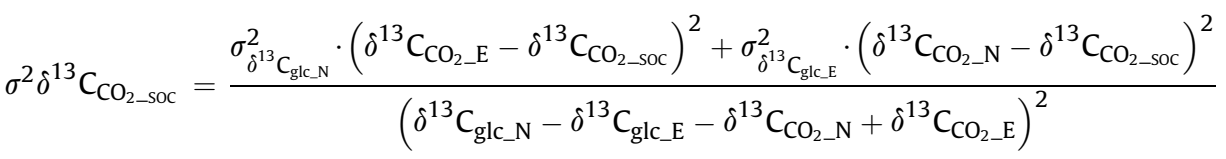

$$
\begin{aligned}
& +\frac{\sigma^{13} \mathrm{C}_{\mathrm{CO}_{2}-\mathrm{N}} \cdot\left(\delta^{13} \mathrm{C}_{\mathrm{glc} \_\mathrm{E}}-\delta^{13} \mathrm{C}_{\mathrm{CO}_{2 \_-S O C}}\right)^{2}+\sigma^{2}{ }^{13} \mathrm{C}_{\mathrm{CO}_{2} \mathrm{E}} \cdot\left(\delta^{13} \mathrm{C}_{\mathrm{glc}_{-} \mathrm{N}}-\delta^{13} \mathrm{C}_{\mathrm{CO}_{2-5 \mathrm{SOC}}}\right)^{2}}{\left(\delta^{13} \mathrm{C}_{\mathrm{glc} \_\mathrm{N}}-\delta^{13} \mathrm{C}_{\mathrm{glc} \_\mathrm{E}}-\delta^{13} \mathrm{C}_{\mathrm{CO}_{2 \_} \mathrm{N}}+\delta^{13} \mathrm{C}_{\mathrm{CO}_{2 \_} \mathrm{E}}\right)^{2}}
\end{aligned}
$$




\section{References}

Amelung, W., Brodowski, S., Sandhage-Hofmann, A., Bol, R., 2008. Combining Biomarker with Stable Isotope Analyses for Assessing the Transformation and Turnover of Soil Organic Matter. In: Advances in Agronomy. Academic Press, Burlington, pp. 155-250.

Bai, M., Köstler, M., Kunstmann, J., Wilske, B., Gattinger, A., Frede, H.G., Breuer, L., 2011. Biodegradability screening of soil amendments through coupling of wavelength-scanned cavity ring-down spectroscopy to multiple dynamic chamber. Rapid Communications in Mass Spectrometry 25, 3683-3689.

Bailey, V.L., Peacock, A.D., Smith, J.L., Bolton Jr., H., 2002. Relationships between soil microbial biomass determined by chloroform fumigation-extraction, substrate induced respiration, and phospholipid fatty acid analysis. Soil Biology and Biochemistry 34, 1385-1389.

Bastida, F., Torres, I.F., Hernandez, T., Bombach, P., Richnow, H.H., Garcia, C., 2013. Can the labile carbon contribute to carbon immobilization in semiarid soils? Priming effects and microbial community dynamics. Soil Biology and Biochemistry 57, 892-902.

Bird, J.A., Herman, D.J., Firestone, M.K., 2011. Rhizosphere priming of soil organic matter by bacterial groups in a grassland soil. Soil Biology and Biochemistry 43, $718-725$.

Blagodatskaya, E.V., Blagodatsky, S.A., Anderson, T.-H., Kuzyakov, Y., 2007. Priming effects in Chernozem induced by glucose and $\mathrm{N}$ in relation to microbial growth strategies. Applied Soil Ecology 37, 95-105.

Blagodatskaya, E.V., Kuzyakov, Y., 2008. Mechanisms of real and apparent priming effects and their dependence on soil microbial biomass and community structure: critical review. Biology and Fertility of Soils 45, 115-131.

Blagodatskaya, E.V., Yuyukina, T., Blagodatsky, S.A., Kuzyakov, Y., 2011. Threesource-partitioning of microbial biomass and of $\mathrm{CO}_{2}$ efflux from soil to evaluate mechanisms of priming effects. Soil Biology and Biochemistry 43, 778-786.

Blagodatskaya, E.V., Kuzyakov, Y., 2013. Active microorganisms in soil: critical review of estimation criteria and approaches. Soil Biology and Biochemistry 67, 192-211.

Blagodatskaya, E.V., Khomyakov, N., Myachina, O., Bogomolova, I., Blagodatsky, S.A., Kuzyakov, Y., 2014. Microbial interactions affect sources of priming induced by cellulose. Soil Biology and Biochemistry 74, 39-49.

Boschker, H.T.S., Moerdijk-Poortvliet, T.C.W., van Breugel, P., Houtekamer, M., Middelburg, J.J., 1999. A versatile method for stable carbon isotope analysis of carbohydrate by high-performance liquid chromatography/isotope ratio mass spectrometry. Rapid Communications in Mass Spectrometry 22, 1-7.

Boschker, H.T.S., 2004. Linking microbial community structure and functioning: stable isotope (13C) labeling in combination with PLFA analysis. In: Kowalchuk, G.A., de Bruijn, F.J., Head, I.M., Akkermans, A.D., van Elsas, J.D. (Eds.), Microbial Ecology. Kluwer Academic Publishers, Dordrecht, The Netherlands, pp. $1673-1688$.

De Nobili, M., Contin, M., Mondini, C., Brooks, P.C., 2001. Soil microbial biomass is triggered into activity by trace amounts of substrate. Soil Biology and Biochemistry 33, 1163-1170.

Derrien, D., Marol, C., Balabane, M., Balesdent, J., 2006. The turnover of carbohydrates in a cultivated soil estimated by ${ }^{13} \mathrm{C}$ natural abundances. European Journal of Soil Science 57, 547-557.

Derrien, D., Marol, C., Balesdent, J., 2007. Microbial biosyntheses of individual neutral sugars among a set of substrates and soils. Geoderma 139, 190-197.

Dungait, J.A.J., Kemmitt, S.J., Michallon, L., Guo, S., Wen, Q., Brooks, P.C., Evershed, R.P., 2011. Variable responses of the soil microbial biomass to trace concentrations of ${ }^{13} \mathrm{C}$-labelled glucose, using ${ }^{13} \mathrm{C}$-PLFA analysis. European Journal of Soil Science 62, 117-126.

Dungait, J.A.J., Kemmitt, S.J., Michallon, L., Guo, S., Wen, Q., Brooks, P.C., Evershed, R.P., 2013. The variable response of soil microorganisms to trace concentrations of low molecular weight organic substrates of increasing complexity. Soil Biology and Biochemistry 64, 57-64.

Ekblad, A., Nyberg, G., Högberg, P., 2002. ${ }^{13}$ C-discrimination during microbial respiration of added $\mathrm{C}_{-}-, \mathrm{C} 4-$ and ${ }^{13} \mathrm{C}$-labelled sugars to a $\mathrm{C} 3$-forest soil. Oecologia 131, 245-249.

Epron, D., Marsden, C., Thongo M'Bou, A., Saint-Andre, L., d'Annunzio, R., Nouvellon, Y., 2009. Soil carbon dynamics following afforestation of a tropical savannah with Eucalyptus in Congo. Plant Soil 323, 309-322.

Epron, D., Ngao, J., Dannoura, M., Bakker, M.R., Zeller, B., Bazot, S., Bosc, A., Plain, C., Lata, J.C., Priault, P., Barthes, L., Loustau, D., 2011. Seasonal variations of belowground carbon transfer assessed by in situ ${ }^{13} \mathrm{CO}_{2}$ pulse labelling of trees. Biogeosciences 8 (5), 1153-1168.

Fontaine, S., Mariotti, A., Abbadie, L., 2003. The priming effect of organic matter: a question of microbial competition? Soil Biology and Biochemistry 35, 837-843.

Fontaine, S., Henault, C., Aamor, A., Bdioui, N., Bloor, J.M.G., Maire, V., Mary, B. Revaillot, S., Maron, P.A., 2011. Fungi mediate long term sequestration of carbon and nitrogen in soil through their priming effect. Soil Biology and Biochemistry $43,86-96$.

Garland, J.L., 1996. Analytical approaches to the characterization of samples of microbial communities using patterns of potential C source utilization. Soil Biology and Biochemistry 28, 213-221.

Griffis, T.J., Baker, J.M., Sargent, S.D., Tanner, B.D., Zhang, J., 2004. Measuring fieldscale isotopic $\mathrm{CO}_{2}$ fluxes with tunable diode laser absorption spectroscopy and micrometeorological techniques. Agricultural and Forest Meteorology 124 (1-2), 15-29.

Hamer, U., Marschner, B., 2005. Priming effects in different soil types induced by fructose, alanine, oxalic acid and catechol additions. Soil Biology and Biochemistry 37, 445-454.

Hill, P.W., Farrar, J.F., Jones, D.L., 2008. Decoupling of microbial glucose uptake and mineralization in soil. Soil Biology and Biochemistry 40, 616-624.

IPCC, 2004. Good Practice Guidance for Land Use, Land-use Change and Forestry, Intergovernmental Panel on Climate Change.

Jenkinson, D.S., Brooks, P.C., Powlson, D.S., 2004. Measuring soil microbial biomass. Soil Biology and Biochemistry 36, 5-7.

Kramer, C., Gleixner, G., 2008. Soil organic matter in soil depth profiles: distinct carbon preference of microbial groups during carbon transformation. Soil Biology and Biochemistry 40, 425-433.

Kuzyakov, Y., 2010. Priming effects: interactions between living and dead organic matter. Soil Biology and Biochemistry 42, 1363-1371.

Kuzyakov, Y., Bol, R., 2004. Using natural ${ }^{13} \mathrm{C}$ abundances to differentiate between three $\mathrm{CO} 2$ sources during incubation of a grassland soil amended with slurry and sugar. Journal of Plant Nutrition and Soil Science 167, 669-677.

Lal, R., 2005. Forest soils and carbon sequestration. Forest Ecol. Manag 220, 242-248.

Löhnis, F., 1926. Nitrogen availability of green manures. Soil Science 22, 171-177.

Mareschal, L., Laclau, J.P., Nzila, J.D.D., Versini, A., Koutika, L.S., Mazoumbou, J.C. Deleporte, P., Bouillet,J.-P., Ranger,J., 2013. Nutrient leaching and deep drainage under Eucalyptus plantations managed in short rotations after afforestation of an African savanna: two 7-year time series. Forest Ecology and Management 307, 242-254.

Marron, N., Plain, C., Longdoz, B., Epron, D., 2009. Seasonal and daily time course of the ${ }^{13} \mathrm{C}$ composition in soil $\mathrm{CO}_{2}$ efflux recorded with a tunable diode laser spectrophotometer (TDLS). Plant Soil 318, 137-151.

Meisner, A., Baath, E., Rousk, J., 2013. Microbial growth responses upon rewetting soil dried for four days or one year. Soil Biology and Biochemistry 66, 188-192.

Middelburg, J.J., Barranguet, C., Boschker, H.T.S., Herman, P.M.J., Moens, T., Heip, C.H.R., 2000. The fate of intertidal microphytobenthos carbon: an in situ ${ }^{13} \mathrm{C}$-Labeling study. Limnology and Oceanography 45, 1224-1225.

Midwood, A.J., Millard, P., 2011. Challenges in measuring the $\delta^{13} \mathrm{C}$ of the soil surface CO2 efflux. Rapid Communications in Mass Spectrometry 25, 232-242.

Nottingham, A.T., Griffith, H., Chamberlain, P.M., Scott, A.W., Tanner, A.V.J., 2009. Soil priming by sugar and leaf-litter substrates: a link to microbial groups. Applied Soil Ecology 42, 183-190.

Nottingham, A.T., Turner, L.B., Chamberlain, P.M., Scott, A.W., Tanner, A.V.J., 2012 Priming and microbial nutrient limitation in lowland tropical forest soils of contrasted fertility. Biogeochemistry 111, 219-237.

Pausch, J., Kuzyakov, Y., 2012. Soil organic carbon decomposition from recently added and older sources estimated by $\delta^{13} \mathrm{C}$ values and organic matter. Soil Biology and Biochemistry 55, 40-47.

Phillips, D.L., Gregg, J.W., 2001. Uncertainty in source partitioning using stable isotopes. Oecologia 127, 171-179.

Plain, C., Gérant, D., Maillard, P., Dannoura, M., Dong, Y., Zeller, B., Priault, P., Parent, F., Epron, D., 2009. Tracing of recently assimilated carbon in respiration at high temporal resolution in the field with a tuneable diode laser absorption spectrometer after in situ ${ }^{13} \mathrm{CO}_{2}$ pulse labelling of 20 -year-old beech trees. Tree Physiol 29, 1433-1447.

Schneckenberger, K., Demin, D., Kuzyakov, Y., 2008. Microbial utilization and mineralisation of $\left[{ }^{14} \mathrm{C}\right]$ glucose added in six orders of concentration to soil. Soil Biology and Biochemistry 40, 1981-1988.

Stefanowicz, A., 2006. The biolog plates technique as a tool in ecological studies of microbial communities. Polish Journal of Environmental Studies 15, 669-676.

Sullivan, B.W., Hart, S.C., 2013. Evaluation of mechanisms controlling the priming of soil carbon along a substrate age gradient. Soil Biology and Biochemistry 58, 293-301.

Versini, A., Nouvellon, Y., Laclau, J.-P., Kinana, A., Mareschal, L., Zeller, B., Ranger, J., Epron, D., 2013. The manipulation of organic residues affects tree growth and heterotrophic $\mathrm{CO}_{2}$ efflux in a tropical Eucalyptus plantation. Forest Ecology and Management 301, 79-88.

Versini, A., Zeller, B., Derrien, D., Mazoumbou, J.C., Mareschal, L., Saint-André, L., Ranger, J., Laclau, J.P., 2014. The role of harvest residues to sustain tree growth and soil nitrogen stocks in a tropical Eucalyptus plantation. Plant Soil 376, 245-260.

von Lützow, M., Kögel-Knabner, I., Ekschmitt, K., Flessa, H., Guggenberg, G., Matzner, E., Marschner, B., 2007. SOM fractionation methods: relevance to functional pools and stabilization mechanisms. Soil Biology and Biochemistry 39, 2183-2207.

Waldrop, M.P., Firestone, M.K., 2004a. Altered utilization patterns of young and old soil $\mathrm{C}$ by microorganisms caused by temperature shifts and $\mathrm{N}$ additions. Biogeochemistry 67, 235-248.

Waldrop, M.P., Firestone, M.K., 2004b. Microbial community utilization of recalcitrant and simple carbon compounds: impact of oak-woodland plant communities. Oecologia 138, 275-284.

Zelles, L., 1999. Fatty acid patterns of phospholipids and lipopolysaccharides in the characterisation of microbial communities in soil: a review. Biology and Fertility of Soils 29, 111-129.

Zyakun, A.M., Kochetkov, V.V., Baskunov, B.P., Zakharchenko, V.N., Peshenko, V.P. Laurinavichius, K.S., Anokhina, T.O., Siunova, T.V., Sizova, O.I., Boronin, A.M., 2013. Use of glucose and carbon isotope fractionation by microbial cells immobilized on solid-phase surface. Microbiology 82, 280-289. 